\title{
Resisting Foreign Competition - A Case Study of France and Germany
}

Thannaletchimy Thanagopal

Doctoral candidate at University of Paris I Panthéon-Sorbonne and Paris School of Economics, Junior researcher at SEURECO-ERASME Laboratory, Paris, France

thanna.letchimy@gmail.com

Pierre Le Mouel

SEURECO-ERASME Laboratory, Paris, France

pierre.le-mouel@erasme-team.eu
CroEconSur

Vol. 16

No. 1

April 2014

pp. $75-108$

Received: January 15, 2014

Accepted: March 11, 2014

Research Article

doi:10.15179/ces.16.1.3

\section{Abstract}

This article incorporates both the new trade and the endogenous growth theories to study the determinants of import volumes of France and Germany so as to explain their individual industrial competitiveness strategies - price or quality competition. This article is different because it studies competitiveness of a country's products by considering its resistance to foreign competition rather than considering exports of these countries. Using disaggregated bilateral data for 16 European countries including Japan and the United States across 15 distinctly classified industries over a period of 20 years (between 1991 and 2010), we use an import demand equation to compare the relative product performances of France and Germany vis-à-vis their exporting competitors. To eliminate the price endogeneity problem, we implement a Two Stage Least Squares (2SLS) estimation technique using the cost of production (which 
includes the unit labor cost and costs of capital and intermediates), mark-up and distance as instrumental variables for import prices. We also proxy innovation and hence product quality using research and development (R\&D) intensity, reported in Product Field. We find that French products are highly substitutable vis-à-vis their foreign competitors in contrast to German products. Germany adopts better quality competitive strategies, thus rendering their products less substitutable and highly differentiated vis-à-vis their foreign counterparts.

Keywords: competitiveness, product quality, innovation efforts, 2SLS, France, Germany

JEL classification: F12, F13, F14, F49

\section{Introduction ${ }^{1}$}

This article incorporates both the new trade and the endogenous growth theories to study the determinants of import volumes of France and Germany so as to explain their individual product performance vis-à-vis their foreign competitors. In particular, this article analyzes French and German competitiveness strategies - price competition (lowering domestic prices) or quality competition (improving domestic product quality). This article differs from most studies in two aspects. First, this article attempts to study the product performance of a country by considering its resistance to foreign competitors. In particular, we are interested in looking at the substitutability of French and German products in contrast to their imports. The domestic product performs better and becomes more competitive if it is less substitutable and highly differentiable. Secondly, this article introduces original instruments for import prices and an improved proxy for product quality. Instead of the conventional use of lagged prices as instrumental variables, we use

1 We are extremely grateful to Gabriel Galand for creating the extensive database of disaggregated bilateral trade flows which has been used for this study. We would also like to thank our colleagues Gilles Koleda and Paul Zagamé for their insightful contribution to this paper. In addition, we would like to extend our gratitude to our other colleagues, especially Arnaud Fougeyrollas, Baptiste Boitier, Boris Le Hir, Florent Pratlong, and Nicholas Lancesseur at the SEURECO laboratory for their insightful comments and constructive criticism. Any apparent errors in this paper are our sole responsibility. 
cost of production (which includes the unit labor cost and costs of capital and intermediates), mark-up and bilateral distance as instruments for the price of products. The use of these instruments helps to eliminate the problem of price endogeneity that often leads to underestimated import price elasticity (ErkelRousse and Mirza, 2002). In addition, we proxy innovation and hence product quality using an improved research and development (R\&D) intensity which is calculated using R\&D expenditures reported in Product Field ${ }^{2}$ divided by Value Added (VA). R\&D expenditures reported in Product Field capture the 'true' expenditure in research by firms since it includes outsourced and secondary research spending unlike $\mathrm{R} \& \mathrm{D}$ expenditures reported in Main Activity. In using disaggregated bilateral data for 16 countries (EU-14 excluding Luxembourg and including Japan and the United States) across 15 distinctly classified industries over a period of 20 years (between 1991 and 2010), we compare the response of French and German import demand to differences in domestic and foreign product prices and product quality. We find that French products may be highly substitutable vis-à-vis their foreign competitors as opposed to German products. On the other hand, German products (especially in sectors producing highly differentiated products) practice better competitive strategies than French products since they tend to be less substitutable and highly differentiated vis-àvis their foreign counterparts.

The outline of this paper is as follows: Section 2 establishes the relevance of our article by considering recent economic literature in this field. Section 3 describes the empirical model in detail while Section 4 explains how the empirical model is to be estimated. Section 5 reports the results of our study and provides an analysis of the results and finally Section 6 concludes the paper.

2 Product Field refers to activities of a firm that pertain to the product, including secondary activities of the firm. This is different from Main Activity which refers to the principal activity of the firm and excludes all secondary activities. For instance, a car manufacturing firm's Main Activity is to manufacture cars. So any expenditure on research recorded under Main Activity will only include amount spent in research pertaining to car manufacturing directly. If this firm also undertakes secondary activities or is highly diversified, the expenditure pertaining to its secondary activities will not be recorded under Main Activity, but rather under Product Field. 


\section{Literature Review on Product Prices, Product Quality and Trade Competitiveness}

Recent economic literature has highlighted the loss of French price competitiveness as being due to its higher labor costs and hence higher product prices (Artus and Fontagné, 2006). In contrast, Germany is shown to have improved in this area as it was previously weaker in terms of price competitiveness right after the fall of the Berlin Wall (Didier and Koléda, 2011; Trésor-Economics, 2009; Fontagné and Gaulier, 2008 and ECB, 2005). This paper enriches the analysis of the loss of French competitiveness in contrast to the German case by offering an alternative way of looking at this issue. Most relevant studies have considered this problem by focusing on the export potential of France and Germany respectively when defining their product performance. We, on the other hand, consider the competition between the domestic product and its foreign competitor within the context of the domestic market. A country that is able to compete in its own domestic market vis-à-vis its foreign counterparts is considered competitive in its own market. In this way, we attempt to reconsider the loss of French competitiveness as a result of higher substitutability and hence lower product differentiation when competing against EU-14, Japan and the United States imports. To do so, we consider an import demand model that will be explained in more detail in Section 3.

Traditionally, trade is determined by factors like prices, incomes of trading partners and distance. More recent studies have contributed to the basic empirical model by acknowledging that product differentiation and thus product quality play an important role in determining trade. As such, recent empirical models usually include product quality with the traditional factors to explain crosscountry differences in trade performance. ${ }^{3}$

3 For instance, Hallak (2006) investigates the importance of cross-country differences in product quality in determining the direction of trade, assuming that quality is the main factor that explains the difference in the unit values observed for highly detailed categories of products. In his empirical analysis, he finds evidence for one of the predictions of Linder hypothesis (Johnson, 1964), that is, rich countries consume more high quality goods than poorer countries. Fontagné, Gaulier and Zignago (2007) use unit values of trade flows to investigate the patterns of specialization of countries within products and find that bilateral trade in high quality products is more intense when both countries are from the North whereas it is more intense in low quality products between South countries. 
However, data required for such empirical analysis are fraught with problems ranging from data mismeasurement to unobservable variables. Erkel-Rousse and Mirza (2002) were some of the first economists to raise the problem of price endogeneity in trade equations. They argued that there are endogenous links between prices and trade volumes which, if not corrected for with quality, can result in biased import price elasticities. As noted by Erkel-Rousse and Mirza (2002: 3), "in a competitive or a traditional oligopolistic setting, prices and quantities must adjust simultaneously, which leads to non-orthogonal price and residual vectors in a trade equation". In a monopolistic framework, prices may not depend on quantities since prices are derived from marginal costs and are inflated by mark-ups. In this framework, although prices may not depend on product quantities, bias can still arise if the trade equation does not account for product differentiation and hence product quality, and if prices are mismeasured or are not correctly purged from quality effects (Hallak and Schott, 2011).

The next problem arises due to the presence of the unobservable variable of product quality. Initially, economists used direct R\&D expenditures, number of patent citations and human capital variables as proxies for product quality (Eaton and Kortum, 2002; Anderton, 1999; Ioannidis and Schreyer, 1997). This trend has changed recently as economists increasingly use trade unit values as quality proxies (Fieler, 2011; Fontagné, Gaulier and Zignago, 2007; Hallak, 2006). However, the recently published works by Hallak and Schott (2011) and Khandelwal (2010) have contested against the use of unit values as proxies for quality since export prices are affected by factors other than quality, such as production costs.

Diverging from the use of prices and quantities to infer product quality, some economists have created their own quality measures using microdata as with Crozet, Head and Mayer (2011) and notably, Crozet and Erkel-Rousse (2004) who used a quality perceptions survey to determine the preferences of consumers for quality products coming from particular exporting countries. However, such indirect measures of product quality serve to capture very specific dimensions 
of product quality, notably technological differentiation while ignoring the demand-side aspects that define quality via consumer preferences.

Acknowledging the shortcomings in trade data and in current economic literature, our article revisits the issue of price endogeneity in trade equations. Erkel-Rousse and Mirza (2002) proposed the use of sophisticated econometric methods to counter the price endogeneity problem. We use a Two Stage Least Squares (2SLS) technique using original instruments for prices. As prices are made up of production costs and margins, in the context of monopolistic competition, we introduce the cost of production (which includes the unit labor cost and costs of capital and intermediates), mark-up and bilateral distance as instrumental variables for product prices.

With regards to measuring product quality, we have opted to use the traditional and indirect measure of product innovation and hence product quality which is R\&D expenditures. Our contribution to this traditional proxy is twofold. First, we acknowledge the existence of an underestimation bias involved in reported $\mathrm{R} \& \mathrm{D}$ expenditures. In fact, empirical papers that use $\mathrm{R} \& \mathrm{D}$ expenditures as a proxy for product quality use readily available data on $R \& D$ expenditures, which are dominantly reported in Main Activity. However, R\&D expenditures reported in Main Activity tend to underestimate secondary innovative efforts by enterprises outside of their Main Activity. For instance, an automobile enterprise may spend its primary $R \& D$ expenditures on improving automobile quality. But, it may also spend a significant amount of $R \& D$ efforts on marketing strategies which are also related to increasing product quality. Thus, reporting R\&D expenditures in Main Activity often underestimates such secondary spending. These expenditures should be reported in Product Field which consists of total $\mathrm{R} \& \mathrm{D}$ expenditures directly related to improving product quality, be it spending in main activity or in other secondary activities.

The second improvement to the traditional proxy of product quality is to use $R \& D$ intensity rather than $R \& D$ expenditures. We obtain $R \& D$ intensity by 
dividing the R\&D expenditures reported in Product Field by the Value Added. By dividing these expenditures using VA, we control for the scale effects present in innovation efforts. A large country tends to spend a higher proportion of its GDP on innovation efforts compared to a small country. However, this does not necessarily mean that the large country produces higher quality products. By controlling for the scale effects, we can compare better the R\&D efforts of each country against one another.

\section{Model Specification}

Our model is based on the traditional model of import demand and follows closely the import demand model of Anderton (1999) with some differences. The traditional demand for import function is usually expressed in terms of domestic income and price levels:

$\operatorname{In} M_{k t}^{i j}=\alpha_{0}+\alpha_{1} \operatorname{In} P_{k t}^{i}+\beta_{1} \operatorname{In} P_{k t}^{j}+\alpha_{2} \operatorname{In} D_{k t}^{i}$,

where $M_{k t}^{i j}$ is the import volume of country $i$ from an exporter country $j$ for a particular product $k$ over time $t, P_{k t}^{i}$ refers to the domestic price of product $k$ in country $i$ while $P_{k t}^{j}$ refers to the import price of product $k$ originating from country $j$. Finally, $D_{k t}^{i}$ refers to the internal demand of country $i$ for product $k$. Assuming homogeneity of degree zero in prices and money income,${ }^{4}$ we can rewrite Equation (1) using a single relative price variable which explains why economic agents switch their demand between imports and domestic products (Carone, 1996). This specification imposes the following restriction:

$\alpha_{1}+\beta_{1}=0$.

Substituting Equation (2) into Equation (1) gives us the following import demand function:

4 We assume that there is an absence of money illusion, that is, if nominal income and prices both increased by the same proportion, the consumer will not change his demand for a product since he/she understands that there is no change in his/her real income. 


$$
\text { In } M_{k t}^{i j}=\alpha_{0}+\alpha_{1} \operatorname{In} R P_{k t}^{i j}+\alpha_{2} \text { In } D_{k t}^{i},
$$

where $R P_{k t}^{i j}$ refers to the relative price of product $k$, that is, the domestic price of product $k$ with respect to its foreign counterpart.

Anderton (1999) builds on this import demand model by including a relative product quality variable. He assumes that the producers define product prices and product quality through a two-stage process. Firstly, they choose the degree of product differentiation which relates to deciding whether to enter the market while simultaneously choosing on the quality aspect of their product. In the second stage of decision-making, the producer sets prices and quantities for a given level of product quality. On the demand side, based on the prices and quality defined by the producers, the consumer has to choose between the domestic and the foreign good.

Equation (4) gives the import specification of country $i$ (France or Germany in our case):

$$
\operatorname{In} M_{k t}^{i j}=\alpha_{0}+\alpha_{1} \operatorname{In} R P_{k t}^{i j}+\alpha_{2} \operatorname{In} D_{k t}^{i}+\alpha_{3} \operatorname{In} R Q_{k t}^{i j}
$$

where $R Q_{k t}^{i j}$ is relative quality variable of product $k$, that is obtained as a ratio of domestic product quality and imported product quality.

This model is popular in the trade literature as it fuses traditional import demand model with new trade theory and endogenous growth theory through the inclusion of product quality. In addition, it offers an important advantage in the estimation stage. Specifically, it eliminates the problem of multicollinearity which occurs when domestic and import prices are correlated. As such, this model is prevalent in many studies (Chang, Ho and Huang, 2005; Hamori and Matsubayashi, 2001; Anderton, 1999; Ioannidis and Schreyer, 1997). 


\section{Testing the Import Demand Model}

The aim of our study is to adopt the import demand model introduced in Section 3 to study the relative product performance of France and Germany respectively vis-à-vis their foreign counterparts. Our coefficients of interest are $\alpha_{1}$ and $\alpha_{3}$ which correspond to relative product price and relative product quality of France and Germany. We expect $\alpha_{1}>0$ and $\alpha_{3}<0$. If the domestic price of product $k$ is much higher in $i$ as opposed to that of $j$, the imports coming to $i$ should increase.

Similarly, if the domestic product quality of $k$ is higher than the foreignproduced $k$, consumers would choose to buy from domestic producers, due to their preference for higher quality, leading to a fall in imports originating from $j$.

We use data compiled for a group of 16 countries namely Austria, Belgium, Denmark, Germany, Spain, the United States, Finland, France, Greece, Ireland, Italy, Japan, Netherlands, Portugal, Sweden and the United Kingdom, over the period 1991 to 2010 for a total of 15 manufacturing industries. We obtained the import volumes from the CHELEM database. The database provides trade data disaggregated across 72 product categories which were reorganized to fit our 15 product sectors. ${ }^{5}$

To eliminate the problem of price endogeneity that is present in trade equations, we implement a 2 SLS technique by using instrumental variables for product prices. Instead of using the conventional lagged prices as instrumental variables, we introduce three separate instruments - cost of production (which includes unit labor $\operatorname{cost}^{6}$ and costs of capital and intermediates), mark-up ${ }^{7}$ and bilateral distance between importer and exporter country. Due to the panel structure

5 Special acknowledgement to Gabriel Galand, of SEURECO Laboratory, for constructing the disaggregated bilateral trade flow database by compiling these various databases listed in the text to eliminate missing trade values. In addition, he is also responsible for creating the extensive and complete database used for the purpose of this study.

6 The unit labor cost, otherwise known as the productivity adjusted labor cost, is defined as the ratio of the nominal labor costs over the nominal value added of the products. The nominal cost of labor was obtained using STAN and the Labor Costs database from the Bureau of Labor Statistics.

7 Mark-up values in our analysis are obtained by dividing the gross operating surplus by value added using data from STAN. 
of our data, we also use country effects as instruments. We assume that the instruments influence directly the costs of production and hence the product prices so as to affect import demand. ${ }^{8}$ The reason for using bilateral distances as one of the instruments is to account for the existence of trade margins. Distance data is obtained from GeoDist via CEPII (Mayer and Zignago, 2011). GeoDist provides bilateral distances between the major cities of the countries, using citylevel data in a bid to assess the geographic distribution of the population inside each country and it is measured in kilometers.

Internal demand is proxied using the total final expenditure of the importer country for a particular product $k$. This data is obtained from the OECD STAN database.

Product quality is proxied using R\&D intensity. To calculate this variable, we used OECD STAN database. In particular, R\&D expenditures obtained from STAN are reported in Main Activity for a majority of the countries, while only 6 countries report their expenditures in both Main Activity and Product Field. The Frascati Manual, which is the guide used by STAN to collate R\&D data, recommends that countries report $\mathrm{R} \& \mathrm{D}$ expenditures on an enterprise basis (Main Activity). This implies that all the R\&D expenditures of a diversified enterprise will be allocated to the industrial class of its principal activity. In cases where a few large enterprises dominate $\mathrm{R} \& \mathrm{D}$ spending in several areas, this leads to an underestimated reporting of $\mathrm{R} \& \mathrm{D}$ expenditures. Thus, a better way to calculate 'true' R\&D expenditures across industries is to report these spendings in Product Field.

Using the sample of 6 countries who have reported their R\&D spending in both Main Activity and Product Field, we were able to estimate the level of bias in R\&D reported under Main Activity using a simple linear regression. We then

8 Production costs not only depend on labor costs, but also on the cost of other factors of production such as energy and intermediates. This is especially true in the manufacturing sector of France and Germany that are very integrated in the European global value chain. This aspect of value chain needs to be addressed when we consider intermediate products since both France and Germany import a rising share of intermediate goods. Hence, we include the costs of intermediates as one of our instruments. The study of value chain requires much attention, but we leave it out in this study. In doing so, we restrict our product sample to include only trade in final goods. 
correct the bias for all other countries in our study using the estimated bias values that we find and finally divide these values using industrial value added to obtain the R\&D intensity that is relevant for our study. A detailed version of this methodology is provided in Appendix.

The main reason for choosing a dominant European database is that we recognize the fact that both France and Germany import extensively from their European neighbors. In Table 1, we present the average share of French and German imports (for period 1991 to 2010) from their Western European partners (namely EU-14 countries in our sample), the US and Japan. In this way, we are able to explain the dominant import volumes in France and Germany using bilateral trade volumes from European exporting countries in our sample.

Table 1: Import Shares of France and Germany (in \%)

\begin{tabular}{l|c|c}
\hline Export Partners & France & Germany \\
\hline EU-14 countries & 84.7 & 85.0 \\
United States & 8.13 & 8.70 \\
Japan & 7.17 & 6.30 \\
\hline
\end{tabular}

Source: Author's own calculation using CHELEM database.

Table 2 provides a description of the list of final goods industries used in our study. Furthermore, we classify the industries according to whether they produce highly homogenous products (HOM) or highly differentiated products (DIF) according to two separate studies done by Rauch (1999) and Oliveira-Martins, Scarpetta and Pilat (1996) which we use to generalize our results in Section 5. 
Table 2: List of Manufacturing Industries in Sample

\begin{tabular}{c|l|c|c}
\hline Industry & \multicolumn{1}{|c|}{$\begin{array}{c}\text { Product } \\
\text { differentiation by } \\
\text { Rauch }\end{array}$} & $\begin{array}{c}\text { Product } \\
\text { differentiation by } \\
\text { OMSP }\end{array}$ \\
\hline 1 & Agriculture and Fishing & HOM & HOM \\
\hline 2 & All extractions & HOM & HOM \\
\hline 3 & Distribution of water, gas and electricity & HOM & HOM \\
\hline 4 & Coke, Refined Oil and Nuclear Fuels & HOM & HOM \\
\hline 5 & Basic Metals and Metal Products & DIF & HOM \\
\hline 6 & Non-metallic Mineral Products & DIF & DIF \\
\hline 7 & Chemicals & DIF & DIF \\
\hline 8 & Agricultural and Industrial Machines & DIF & DIF \\
\hline 9 & Office Machines and Electrical Goods & DIF & HOM \\
\hline 10 & Transport Equipment & DIF & HOM \\
\hline 11 & Food, Drink and Tobacco & HOM & HOM \\
\hline 12 & Textiles, Cloth and Footwear & DIF & HOM \\
\hline 13 & Paper and Printing Products & DIF & DIF \\
\hline 14 & Rubber and Plastic & DIF & \\
\hline 15 & Other Manufactures & DIF & \\
\hline
\end{tabular}

\section{Main Econometric Results}

We estimate the following equation using 2SLS technique in which prices are instrumented through the use of unitary costs of production (of labor, capital and intermediates), mark-ups and bilateral distances.

$$
\begin{aligned}
\text { In } M_{k t}^{i j}= & \alpha_{0}+\alpha_{1} \text { In } R P_{k t}^{i j}+\alpha_{2} \text { In } D_{k t}^{i}+\alpha_{3} \text { In } R Q_{k t}^{i j}+\alpha_{4} E U+ \\
& +\alpha_{5} \text { Time }+\alpha_{6} \text { In } R P_{k t}^{i j} * D_{F R}+\alpha_{7} \text { In } D_{k t}^{i} * D_{F R}+ \\
& +\alpha_{8} \text { In } R Q_{k t}^{i j} * D_{F R}+\alpha_{9} E U+\alpha_{10} \text { Time } * D_{F R}+\alpha_{11} D_{F R}+F E_{E x p}
\end{aligned}
$$

Instead of running the regression for the case of France and then for the case of Germany, we ran a pooled regression of Equation (5) for each industry using importer fixed effects and interaction terms to allow for comparisons between French and German coefficients of price, quality and demand. Our sample includes the bilateral trade between France and Germany. We also included control variables such as a European Union dummy, $E U$, which equals 1 if both 
countries are in the EU and 0 otherwise, exporter fixed effects ${ }^{9}\left(F E_{E x p}\right)$ as well as a time trend (Time). ${ }^{10}$ To differentiate the effects of the dependent variables on France and Germany, we include a dummy variable, $D_{F R}$, which equals 1 if the importing country is France and 0 otherwise. Interaction dummies are added to study the different impact of price, demand and quality on French and German domestic markets. Table 3 presents the results of the pooled regression. The results are disaggregated across the 15 manufacturing industries in our sample. ${ }^{11}$

Table 3: Pooled Regression

\begin{tabular}{|c|c|c|c|c|c|c|c|}
\hline Industry & 1 & 2 & 3 & 4 & 5 & 6 & 7 \\
\hline$\alpha_{1}$ & $\begin{array}{r}6.899^{* * *} \\
(1.537)\end{array}$ & $\begin{array}{r}4.614^{* * *} \\
(0.695)\end{array}$ & $\begin{array}{c}1.544^{* *} \\
(0.106)\end{array}$ & $\begin{array}{r}1.387^{* * *} \\
(0.125)\end{array}$ & $\begin{array}{r}1.872^{* * * *} \\
(0.935)\end{array}$ & $\begin{array}{r}5.175^{*} \\
(2.363)\end{array}$ & $\begin{array}{r}2.251 \\
(1.662)\end{array}$ \\
\hline$\alpha_{2}$ & $\begin{array}{r}1.736^{* * *} \\
(0.135)\end{array}$ & $\begin{array}{r}1.446^{* * *} \\
(0.426)\end{array}$ & $\begin{array}{r}2.966 \\
(6.053)\end{array}$ & $\begin{array}{r}1.729 \\
(0.907)\end{array}$ & $\begin{array}{c}1.58^{* *} \\
(0.167)\end{array}$ & $\begin{array}{l}3.007^{*} \\
(1.361)\end{array}$ & $\begin{array}{r}2.476 \\
(1.557)\end{array}$ \\
\hline$\alpha_{3}$ & $\begin{array}{r}-1.071^{* * *} \\
(0.106)\end{array}$ & $\begin{array}{c}-0.165^{*} \\
(0.075)\end{array}$ & $\begin{array}{l}-0.456 \\
(0.415)\end{array}$ & $\begin{array}{r}-0.932^{* * *} \\
(0.166)\end{array}$ & $\begin{array}{r}-0.866^{* * *} \\
(0.227)\end{array}$ & $\begin{array}{r}-0.589^{* * *} \\
(0.121)\end{array}$ & $\begin{array}{l}-0.244 \\
(0.152)\end{array}$ \\
\hline$\alpha_{4}$ & $\begin{array}{c}0.937^{* *} \\
(0.289)\end{array}$ & $\begin{array}{r}1.307^{* * *} \\
(0.330)\end{array}$ & $\begin{array}{r}7.805^{* * *} \\
(1.124)\end{array}$ & $\begin{array}{r}1.962^{* * *} \\
(0.531)\end{array}$ & $\begin{array}{r}0.415 \\
(0.427)\end{array}$ & $\begin{array}{r}0.496 \\
(0.344)\end{array}$ & $\begin{array}{c}0.572^{*} \\
(0.291)\end{array}$ \\
\hline$\alpha_{5}$ & $\begin{array}{r}0.353^{* * *} \\
(0.066)\end{array}$ & $\begin{array}{c}0.197^{* * *} \\
(0.046)\end{array}$ & $\begin{array}{c}-0.596 \\
(0.377)\end{array}$ & $\begin{array}{r}0.919^{* * *} \\
(0.137)\end{array}$ & $\begin{array}{r}0.875^{* * *} \\
(0.180)\end{array}$ & $\begin{array}{r}0.210^{* * *} \\
(0.077)\end{array}$ & $\begin{array}{c}0.254^{* *} \\
(0.094)\end{array}$ \\
\hline$\alpha_{6}$ & $\begin{array}{c}-0.929 \\
(2.168)\end{array}$ & $\begin{array}{l}-3.026^{*} \\
(1.234)\end{array}$ & $\begin{array}{r}3.847^{* * *} \\
(1.243)\end{array}$ & $\begin{array}{r}-1.293^{* * *} \\
(0.129)\end{array}$ & $\begin{array}{c}-1.713 \\
(5.724)\end{array}$ & $\begin{array}{c}-1.039 \\
(3.635)\end{array}$ & $\begin{array}{l}1.550^{* *} \\
(0.895)\end{array}$ \\
\hline$\alpha_{7}$ & $\begin{array}{r}2.725 \\
(2.411)\end{array}$ & $\begin{array}{l}-0.323 \\
(0.721)\end{array}$ & $\begin{array}{c}1.20^{* *} \\
(0.118)\end{array}$ & $\begin{array}{c}2.398 \\
(1.279)\end{array}$ & $\begin{array}{r}0.057 \\
(4.025)\end{array}$ & $\begin{array}{c}-2.836 \\
(2.214)\end{array}$ & $\begin{array}{c}1.093^{*} \\
(0.466)\end{array}$ \\
\hline$\alpha_{8}$ & $\begin{array}{l}0.221 \\
(0.15)\end{array}$ & $\begin{array}{l}-0.184 \\
(0.119)\end{array}$ & $\begin{array}{l}-1.339 * \\
(0.629)\end{array}$ & $\begin{array}{r}-0.795^{* * *} \\
(0.237)\end{array}$ & $\begin{array}{c}-0.770^{*} \\
(0.332)\end{array}$ & $\begin{array}{c}-0.429^{*} \\
(0.173)\end{array}$ & $\begin{array}{l}-0.237 \\
(0.218)\end{array}$ \\
\hline$\alpha_{9}$ & $\begin{array}{r}0.18 \\
(0.373)\end{array}$ & $\begin{array}{l}-0.268 \\
(0.458)\end{array}$ & $\begin{array}{r}-4.200^{* *} \\
(1.489)\end{array}$ & $\begin{array}{c}-1.385^{*} \\
(0.692)\end{array}$ & $\begin{array}{l}-0.026 \\
(0.557)\end{array}$ & $\begin{array}{r}0.546 \\
(0.437)\end{array}$ & $\begin{array}{r}0.404 \\
(0.385)\end{array}$ \\
\hline$\alpha_{10}$ & $\begin{array}{r}0.034 \\
(0.109)\end{array}$ & $\begin{array}{r}-0.277^{* * * *} \\
(0.074)\end{array}$ & $\begin{array}{r}2.282^{* * * *} \\
(0.598)\end{array}$ & $\begin{array}{r}-0.825^{* * *} \\
(0.209)\end{array}$ & $\begin{array}{r}0.254 \\
(0.305)\end{array}$ & $\begin{array}{c}-0.152 \\
(0.148)\end{array}$ & $\begin{array}{l}0.659^{* *} \\
(0.206)\end{array}$ \\
\hline $\mathrm{FE}$ & YES & YES & YES & YES & YES & YES & YES \\
\hline Obs. & 600 & 594 & 600 & 596 & 600 & 600 & 600 \\
\hline Adjusted $R^{2}$ & 0.974 & 0.949 & 0.961 & 0.948 & 0.941 & 0.973 & 0.976 \\
\hline $\begin{array}{l}\text { Sargan test } \\
\text { (p-value) }\end{array}$ & $(0.315)$ & $(0.501)$ & $(0.658)$ & $(0.789)$ & $(0.896)$ & $(0.615)$ & $(0.593)$ \\
\hline $\begin{array}{l}\text { Stationarity } \\
\text { test } \\
\text { (p-value) }\end{array}$ & $(0.236)$ & $(0.366)$ & $(0.653)$ & $(0.359)$ & $(0.485)$ & $(0.542)$ & $(0.356)$ \\
\hline
\end{tabular}

9 Given that our data is in panel form, we include exporter fixed effects in our regressions.

10 The time trend accounts for increasing specialization in import penetration over time.

11 As in Anderton (1999), we do not include cross-price and cross-quality variables as we assume that the coefficients of both variables are zero. We did, however, experiment using these two variables and found less satisfactory results. Also, we understand that including individual price and quality variables for each exporter in this equation risks introducing multicollinearity to our model and as such, we assume the coefficients for each exporter is the same across all the exporters. 
Table 3: Pooled Regression - Continued

\begin{tabular}{|c|c|c|c|c|c|c|c|c|}
\hline Industry & 8 & 9 & 10 & 11 & 12 & 13 & 14 & 15 \\
\hline$\alpha_{1}$ & $\begin{array}{r}0.166 \\
(1.684)\end{array}$ & $\begin{array}{r}2.164^{* *} \\
(0.776)\end{array}$ & $\begin{array}{r}6.467^{* *} \\
(1.999)\end{array}$ & $\begin{array}{l}8.096^{*} \\
(3.586)\end{array}$ & $\begin{array}{r}2.106 \\
(1.860)\end{array}$ & $\begin{array}{r}1.197^{* * *} \\
(2.422)\end{array}$ & $\begin{array}{r}6.767^{* * *} \\
(1.328)\end{array}$ & $\begin{array}{r}1.530 \\
(2.626)\end{array}$ \\
\hline$\alpha_{2}$ & $\begin{array}{r}1.410) \\
(1.294)\end{array}$ & $\begin{array}{l}2.468^{*} \\
(1.073)\end{array}$ & $\begin{array}{l}2.904^{*} \\
(1.183)\end{array}$ & $\begin{array}{c}1.874^{*} \\
(0.081)\end{array}$ & $\begin{array}{r}1.235 \\
(1.530)\end{array}$ & $\begin{array}{r}1.342^{* * *} \\
(0.773)\end{array}$ & $\begin{array}{r}4.790^{* *} \\
(1.570)\end{array}$ & $\begin{array}{r}1.131^{* * *} \\
(0.602)\end{array}$ \\
\hline$\alpha_{3}$ & $\begin{array}{r}-0.713^{* * *} \\
(0.162)\end{array}$ & $\begin{array}{r}-1.191^{* * * *} \\
(0.140)\end{array}$ & $\begin{array}{r}-0.872^{* * *} \\
(0.115)\end{array}$ & $\begin{array}{r}-1.021^{* * * *} \\
(0.293)\end{array}$ & $\begin{array}{r}-0.501^{* * *} \\
(0.110)\end{array}$ & $\begin{array}{r}-1.776^{* * *} \\
(0.152)\end{array}$ & $\begin{array}{r}-1.156^{* * *} \\
(0.181)\end{array}$ & $\begin{array}{l}-0.168 \\
(0.112)\end{array}$ \\
\hline$\alpha_{4}$ & $\begin{array}{r}0.622 \\
(0.349)\end{array}$ & $\begin{array}{r}2.081^{* * *} \\
(0.290)\end{array}$ & $\begin{array}{r}1.410^{* * * *} \\
(0.386)\end{array}$ & $\begin{array}{r}2.054^{* * *} \\
(0.336)\end{array}$ & $\begin{array}{r}0.941^{* * * *} \\
(0.284)\end{array}$ & $\begin{array}{r}1.781^{* * *} \\
(0.331)\end{array}$ & $\begin{array}{r}0.193 \\
(0.285)\end{array}$ & $\begin{array}{r}0.298 \\
(0.313)\end{array}$ \\
\hline$\alpha_{5}$ & $\begin{array}{r}0.073 \\
(0.070)\end{array}$ & $\begin{array}{r}0.233^{* * *} \\
(0.066)\end{array}$ & $\begin{array}{r}0.342^{* * *} \\
(0.097)\end{array}$ & $\begin{array}{r}0.389^{* *} \\
(0.131)\end{array}$ & $\begin{array}{l}-0.014 \\
(0.049)\end{array}$ & $\begin{array}{r}-0.398^{* * *} \\
(0.100)\end{array}$ & $\begin{array}{r}-0.216^{* *} \\
(0.076)\end{array}$ & $\begin{array}{r}0.041 \\
(0.055)\end{array}$ \\
\hline$\alpha_{6}$ & $\begin{array}{r}0.674 \\
(2.425)\end{array}$ & $\begin{array}{r}1.552 \\
(1.149)\end{array}$ & $\begin{array}{l}-1.476 \\
(3.043)\end{array}$ & $\begin{array}{r}1.067 \\
(5.598)\end{array}$ & $\begin{array}{r}1.479 \\
(3.310)\end{array}$ & $\begin{array}{l}1.367^{*} \\
(3.623)\end{array}$ & $\begin{array}{r}1.008 \\
(2.545)\end{array}$ & $\begin{array}{r}2.313 \\
(3.492)\end{array}$ \\
\hline$\alpha_{7}$ & $\begin{array}{c}-0.527 \\
(1.779)\end{array}$ & $\begin{array}{l}2.747^{*} \\
(1.332)\end{array}$ & $\begin{array}{c}-0.582 \\
(1.770)\end{array}$ & $\begin{array}{r}1.066 \\
(4.705)\end{array}$ & $\begin{array}{r}1.539 \\
(2.600)\end{array}$ & $\begin{array}{c}-0.508^{*} \\
(0.047)\end{array}$ & $\begin{array}{l}-3.322 \\
(2.571)\end{array}$ & $\begin{array}{r}0.813 \\
(1.091)\end{array}$ \\
\hline$\alpha_{8}$ & $\begin{array}{r}0.156 \\
(0.231)\end{array}$ & $\begin{array}{c}0.566^{* *} \\
(0.198)\end{array}$ & $\begin{array}{r}-0.518^{* *} \\
(0.164)\end{array}$ & $\begin{array}{r}0.634 \\
(0.417)\end{array}$ & $\begin{array}{l}-0.265 \\
(0.170)\end{array}$ & $\begin{array}{r}0.131 \\
(0.223)\end{array}$ & $\begin{array}{c}0.682^{* *} \\
(0.264)\end{array}$ & $\begin{array}{l}-0.232 \\
(0.189)\end{array}$ \\
\hline$\alpha_{9}$ & $\begin{array}{r}0.179 \\
(0.433)\end{array}$ & $\begin{array}{l}1.185^{* *} \\
(0.370)\end{array}$ & $\begin{array}{c}0.999^{*} \\
(0.488)\end{array}$ & $\begin{array}{c}-0.412 \\
(0.434)\end{array}$ & $\begin{array}{l}-0.409 \\
(0.365)\end{array}$ & $\begin{array}{l}-1.013^{*} \\
(0.427)\end{array}$ & $\begin{array}{r}0.220 \\
(0.371)\end{array}$ & $\begin{array}{r}0.219 \\
(0.379)\end{array}$ \\
\hline$\alpha_{10}$ & $\begin{array}{r}0.080 \\
(0.135)\end{array}$ & $\begin{array}{l}-0.119 \\
(0.102)\end{array}$ & $\begin{array}{r}0.019 \\
(0.150)\end{array}$ & $\begin{array}{r}0.322 \\
(0.236)\end{array}$ & $\begin{array}{r}0.272 \\
(0.156)\end{array}$ & $\begin{array}{r}0.225 \\
(0.167)\end{array}$ & $\begin{array}{r}-0.888^{* * *} \\
(0.268)\end{array}$ & $\begin{array}{l}-0.061 \\
(0.103)\end{array}$ \\
\hline $\mathrm{FE}$ & YES & YES & YES & YES & YES & YES & YES & YES \\
\hline Obs. & 600 & 600 & 600 & 600 & 600 & 600 & 600 & 600 \\
\hline Adjusted $R^{2}$ & 0.981 & 0.984 & 0.973 & 0.968 & 0.978 & 0.970 & 0.976 & 0.983 \\
\hline $\begin{array}{l}\text { Sargan test } \\
\text { (p-value) }\end{array}$ & $(0.236)$ & $(0.236)$ & (0.658) & (0.658) & (0.359) & $(0.658)$ & $(0.236)$ & $(0.568)$ \\
\hline $\begin{array}{l}\text { Stationarity } \\
\text { test } \\
\text { (p-value) }\end{array}$ & $(0.542)$ & (0.589) & (0.487) & (0.549) & $(0.258)$ & $(0.247)$ & (0.479) & $(0.784)$ \\
\hline
\end{tabular}

Notes: ${ }^{*},{ }^{* *},{ }^{* * *}$ refer to $10 \%, 5 \%, 1 \%$ significance, respectively, and values in parentheses refer to standard errors: $\alpha_{1}$ refers to relative price coefficient, $\alpha_{2}$ refers to internal demand coefficient, $\alpha_{3}$ refers to relative quality coefficient, $\alpha_{4}$ refers to the EU dummy, $\alpha_{5}$ refers to Time effect, $\alpha_{6}-\alpha_{10}$ refer to the interaction effect with price, demand, quality, EU and time effects, respectively.

The adjusted $R^{2}$ and the standard errors of the variables as shown in parentheses indicate a relatively good fit for a majority of our results, implying that our variables are essential in determining the behavior of bilateral imports. Our coefficients are of the correct sign and are statistically significant at the 95 percent level. As predicted, we obtained positive relative price coefficients and negative relative quality coefficients. Our internal demand coefficient and the EU dummy coefficient are both positive and highly significant. 
The interaction terms can be interpreted as the differential impact of the independent variables between France and Germany. In other words, the interaction terms tell us how the independent effects of prices, demand and quality differ across France and Germany. We observe that the interaction term with the price effect appears to be highly significant and positive in homogeneous sectors, implying that the price coefficient is larger when the importing country is France. Thus, homogeneous goods tend to be more substitutable in France than in Germany when competition is in terms of prices. On the other hand, the interaction term with the quality effect is dominantly positive and insignificant. This signals that the import demand determination is similar between France and Germany when competition is in terms of quality between domestic and foreign goods. In particular, the interaction term appears to be significantly positive in industries producing differentiated goods. This implies that German products are less substitutable to its foreign counterparts than French products in these industries since the quality coefficients tend to be higher in Germany than in France, suggesting a lower substitutability effect between German domestic product and its foreign competitors.

Sargan test results are also reported in Table 3 to validate the use of the 2SLS methodology. The $p$-values are large and do not reject the null hypothesis that the instruments used are valid. We also implemented two measures to ensure that the results are statistically robust. Firstly, we verified that the residuals are stationary by performing a unit root test on the error terms. The $p$-values reported are highly insignificant, thereby not rejecting the null hypothesis that the residuals are stationary. Secondly, we controlled for heteroskedasticity in our regressions through the use of a White estimator.

Tables 4 and 5 present separate results for France and Germany, respectively. The results in Table 4 are obtained from Table 3 when including the impact of the interaction terms on relative prices, internal demand, relative quality, the EU dummy and the time trend. 
Table 4: Results for France

\begin{tabular}{|c|c|c|c|c|c|c|c|}
\hline Industry Code & $\alpha_{1}$ & $\alpha_{2}$ & $\alpha_{3}$ & $\alpha_{4}$ & $\alpha_{5}$ & Obs. & Adjusted $R^{2}$ \\
\hline 1 & $\begin{array}{r}5.970^{* * *} \\
(1.237)\end{array}$ & $\begin{array}{r}4.461^{* * *} \\
(0.132)\end{array}$ & $\begin{array}{r}-0.850^{* * *} \\
(0.102)\end{array}$ & $\begin{array}{r}1.117^{* * *} \\
(0.236)\end{array}$ & $\begin{array}{r}0.387^{* * *} \\
(0.075)\end{array}$ & 600 & 0.974 \\
\hline 2 & $\begin{array}{c}1.588^{* *} \\
(0.721)\end{array}$ & $\begin{array}{c}1.123^{*} \\
(0.580)\end{array}$ & $\begin{array}{r}-0.349^{* * *} \\
(0.086)\end{array}$ & $\begin{array}{r}1.039^{* * *} \\
(0.302)\end{array}$ & $\begin{array}{l}-0.080 \\
(0.061)\end{array}$ & 594 & 0.949 \\
\hline 3 & $\begin{array}{r}5.391^{* * *} \\
(0.470)\end{array}$ & $\begin{array}{r}4.166^{* * *} \\
(0.475)\end{array}$ & $\begin{array}{r}-1.385^{* * *} \\
(0.466)\end{array}$ & $\begin{array}{r}3.605^{* * *} \\
(0.967)\end{array}$ & $\begin{array}{r}1.686^{* * *} \\
(0.391)\end{array}$ & 600 & 0.961 \\
\hline 4 & $\begin{array}{r}0.094 \\
(1.619)\end{array}$ & $\begin{array}{r}4.127^{* * *} \\
(0.857)\end{array}$ & $\begin{array}{r}-1.795^{* * *} \\
(0.145)\end{array}$ & $\begin{array}{r}0.577 \\
(0.432)\end{array}$ & $\begin{array}{r}0.094 \\
(0.125)\end{array}$ & 596 & 0.948 \\
\hline 5 & $\begin{array}{r}0.159^{* * *} \\
(0.038)\end{array}$ & $\begin{array}{r}1.637^{* * *} \\
(0.248)\end{array}$ & $\begin{array}{r}-1.636^{* * *} \\
(0.239)\end{array}$ & $\begin{array}{r}0.389 \\
(0.349)\end{array}$ & $\begin{array}{r}1.129^{* * *} \\
(0.213)\end{array}$ & 600 & 0.941 \\
\hline 6 & $\begin{array}{r}4.136^{* * *} \\
(1.940)\end{array}$ & $\begin{array}{r}0.171 \\
(1.378)\end{array}$ & $\begin{array}{r}-1.018^{* * *} \\
(0.123)\end{array}$ & $\begin{array}{r}1.042^{* * *} \\
(0.249)\end{array}$ & $\begin{array}{r}0.058 \\
(0.100)\end{array}$ & 600 & 0.973 \\
\hline 7 & $\begin{array}{r}3.801^{* * *} \\
(1.937)\end{array}$ & $\begin{array}{r}3.569^{* * *} \\
(1.620)\end{array}$ & $\begin{array}{r}-0.481^{* * *} \\
(0.156)\end{array}$ & $\begin{array}{r}0.976^{* * *} \\
(0.253)\end{array}$ & $\begin{array}{r}0.913^{* * *} \\
(0.161)\end{array}$ & 600 & 0.976 \\
\hline 8 & $\begin{array}{r}0.84 \\
(1.474)\end{array}$ & $\begin{array}{r}0.883 \\
(1.081)\end{array}$ & $\begin{array}{r}-0.557^{* * *} \\
(0.162)\end{array}$ & $\begin{array}{r}0.801^{* * *} \\
(0.236)\end{array}$ & $\begin{array}{r}0.152 \\
(0.106)\end{array}$ & 600 & 0.981 \\
\hline 9 & $\begin{array}{r}3.716^{* * *} \\
(0.645)\end{array}$ & $\begin{array}{r}5.215^{* * *} \\
(0.623)\end{array}$ & $\begin{array}{r}-0.625^{* * *} \\
(0.140)\end{array}$ & $\begin{array}{r}3.266^{* * *} \\
(0.210)\end{array}$ & $\begin{array}{c}0.114^{*} \\
(0.065)\end{array}$ & 600 & 0.984 \\
\hline 10 & $\begin{array}{r}4.991^{* * *} \\
(1.645)\end{array}$ & $\begin{array}{r}2.322^{* * *} \\
(1.046)\end{array}$ & $\begin{array}{r}-1.390^{* * *} \\
(0.117)\end{array}$ & $\begin{array}{r}2.409^{* * *} \\
(0.272)\end{array}$ & $\begin{array}{r}0.361^{* * *} \\
(0.089)\end{array}$ & 600 & 0.973 \\
\hline 11 & $\begin{array}{r}9.163^{* * *} \\
(2.866)\end{array}$ & $\begin{array}{r}2.940^{* * *} \\
(0.245)\end{array}$ & $\begin{array}{l}-0.387 \\
(0.241)\end{array}$ & $\begin{array}{r}1.642^{* * *} \\
(0.269)\end{array}$ & $\begin{array}{r}0.711^{* * *} \\
(0.145)\end{array}$ & 600 & 0.968 \\
\hline 12 & $\begin{array}{r}3.585 \\
(2.124)\end{array}$ & $\begin{array}{l}2.774^{*} \\
(1.718)\end{array}$ & $\begin{array}{r}-0.766^{* *} \\
(0.116)\end{array}$ & $\begin{array}{r}0.532^{* *} \\
(0.215)\end{array}$ & $\begin{array}{c}0.258^{*} \\
(0.132)\end{array}$ & 600 & 0.978 \\
\hline 13 & $\begin{array}{r}2.564^{* * *} \\
(0.222)\end{array}$ & $\begin{array}{r}0.834 \\
(1.442)\end{array}$ & $\begin{array}{r}-1.645^{* * *} \\
(0.154)\end{array}$ & $\begin{array}{r}0.768^{* * *} \\
(0.269)\end{array}$ & $\begin{array}{c}-0.173 \\
(0.115)\end{array}$ & 600 & 0.970 \\
\hline 14 & $\begin{array}{r}7.775^{* * *} \\
(1.953)\end{array}$ & $\begin{array}{r}1.468^{* * *} \\
(0.185)\end{array}$ & $\begin{array}{r}-0.474^{* * *} \\
(0.188)\end{array}$ & $\begin{array}{c}0.413^{*} \\
(0.237)\end{array}$ & $\begin{array}{r}-1.104^{* * *} \\
(0.246)\end{array}$ & 600 & 0.976 \\
\hline 15 & $\begin{array}{l}3.843^{*} \\
(2.148)\end{array}$ & $\begin{array}{l}1.944^{* *} \\
(0.888)\end{array}$ & $\begin{array}{r}-0.400^{* *} \\
(0.149)\end{array}$ & $\begin{array}{c}0.517^{*} \\
(0.213)\end{array}$ & $\begin{array}{l}-0.020 \\
(0.084)\end{array}$ & 600 & 0.983 \\
\hline
\end{tabular}

Note: ${ }^{*},{ }^{* *},{ }^{* * *}$ refer to $10 \%, 5 \%, 1 \%$ significance, respectively, and values in parentheses refer to standard errors; $\alpha_{1}$ refers to relative price coefficient, $\alpha_{2}$ refers to internal demand coefficient, $\alpha_{3}$ refers to relative quality coefficient, $\alpha_{4}$ refers to the EU dummy and $\alpha_{5}$ refers to time effect.

The coefficients reported in the Tables 4 and 5 are static regression results, and as such, the coefficients of relative price, relative quality and demand can be interpreted as reliable estimates of long-run elasticities of price, quality and demand. From our results, we observe that the elasticities of price and demand $\left(\alpha_{1}\right.$ and $\left.\alpha_{2}\right)$ conform to theoretical elasticities which tend to be above one (Krugman, 1979) and are supported by many similar studies (Crozet and ErkelRousse, 2004; Erkel-Rousse and Mirza, 2002; Anderton, 1999). We notice that 
industries producing homogeneous goods tend to display higher price elasticities while industries producing differentiated products report lower price elasticities since they are less substitutable across import competitors. Quality elasticities $\left(\alpha_{3}\right)$ tend to be lower in industries producing homogeneous goods while the reverse is true for industries producing differentiated goods since the scope of product differentiation is higher when the goods are less substitutable.

Table 5: Results for Germany

\begin{tabular}{|c|c|c|c|c|c|c|c|}
\hline Industry Code & $\alpha_{1}$ & $\alpha_{2}$ & $\alpha_{3}$ & $\alpha_{4}$ & $\alpha_{5}$ & Obs. & Adjusted $R^{2}$ \\
\hline 1 & $\begin{array}{r}6.899^{* * *} \\
(1.537)\end{array}$ & $\begin{array}{r}1.736^{* * *} \\
(0.135)\end{array}$ & $\begin{array}{r}-1.071^{* * *} \\
(0.106)\end{array}$ & $\begin{array}{c}0.937^{* *} \\
(0.289)\end{array}$ & $\begin{array}{r}0.353^{* * *} \\
(0.066)\end{array}$ & 600 & 0.974 \\
\hline 2 & $\begin{array}{r}4.614^{* * *} \\
(0.695)\end{array}$ & $\begin{array}{r}1.446^{* * *} \\
(0.426)\end{array}$ & $\begin{array}{l}-0.165^{*} \\
(0.075)\end{array}$ & $\begin{array}{r}1.307^{* * *} \\
(0.330)\end{array}$ & $\begin{array}{r}0.197^{* * *} \\
(0.046)\end{array}$ & 594 & 0.949 \\
\hline 3 & $\begin{array}{c}1.544^{* *} \\
(0.106)\end{array}$ & $\begin{array}{r}2.966 \\
(6.053)\end{array}$ & $\begin{array}{l}-0.456 \\
(0.415)\end{array}$ & $\begin{array}{r}7.805^{* * *} \\
(1.124)\end{array}$ & $\begin{array}{c}-0.596 \\
(0.377)\end{array}$ & 600 & 0.961 \\
\hline 4 & $\begin{array}{r}1.387^{* * *} \\
(0.125)\end{array}$ & $\begin{array}{r}1.729 \\
(0.907)\end{array}$ & $\begin{array}{r}-0.932^{* * *} \\
(0.166)\end{array}$ & $\begin{array}{r}1.962^{* * *} \\
(0.531)\end{array}$ & $\begin{array}{r}0.919^{* * *} \\
(0.137)\end{array}$ & 596 & 0.948 \\
\hline 5 & $\begin{array}{r}1.872^{* * *} \\
(0.935)\end{array}$ & $\begin{array}{l}1.58^{* * *} \\
(0.167)\end{array}$ & $\begin{array}{r}-0.866^{* * *} \\
(0.227)\end{array}$ & $\begin{array}{r}0.415 \\
(0.427)\end{array}$ & $\begin{array}{r}0.875^{* * *} \\
(0.180)\end{array}$ & 600 & 0.941 \\
\hline 6 & $\begin{array}{c}5.175^{*} \\
(2.363)\end{array}$ & $\begin{array}{l}3.007^{*} \\
(1.361)\end{array}$ & $\begin{array}{r}-0.589^{* * *} \\
(0.121)\end{array}$ & $\begin{array}{r}0.496 \\
(0.344)\end{array}$ & $\begin{array}{c}0.210^{* *} \\
(0.077)\end{array}$ & 600 & 0.973 \\
\hline 7 & $\begin{array}{r}2.251 \\
(1.662)\end{array}$ & $\begin{array}{r}2.476 \\
(1.557)\end{array}$ & $\begin{array}{l}-0.244 \\
(0.152)\end{array}$ & $\begin{array}{c}0.572^{*} \\
(0.291)\end{array}$ & $\begin{array}{c}0.254^{* *} \\
(0.094)\end{array}$ & 600 & 0.976 \\
\hline 8 & $\begin{array}{r}0.166 \\
(1.684)\end{array}$ & $\begin{array}{r}1.410 \\
(1.294)\end{array}$ & $\begin{array}{r}-0.713^{* * *} \\
(0.162)\end{array}$ & $\begin{array}{r}0.622 \\
(0.349)\end{array}$ & $\begin{array}{r}0.073 \\
(0.070)\end{array}$ & 600 & 0.981 \\
\hline 9 & $\begin{array}{c}2.164^{* *} \\
(0.776)\end{array}$ & $\begin{array}{l}2.468^{*} \\
(1.073)\end{array}$ & $\begin{array}{r}-1.191^{* * *} \\
(0.140)\end{array}$ & $\begin{array}{r}2.081^{* * *} \\
(0.290)\end{array}$ & $\begin{array}{r}0.233^{* * *} \\
(0.066)\end{array}$ & 600 & 0.984 \\
\hline 10 & $\begin{array}{c}6.467^{* *} \\
(1.999)\end{array}$ & $\begin{array}{l}2.904^{*} \\
(1.183)\end{array}$ & $\begin{array}{r}-0.872^{* * *} \\
(0.115)\end{array}$ & $\begin{array}{r}1.410^{* * *} \\
(0.386)\end{array}$ & $\begin{array}{r}0.342^{* * *} \\
(0.097)\end{array}$ & 600 & 0.973 \\
\hline 11 & $\begin{array}{c}8.096^{*} \\
(3.586)\end{array}$ & $\begin{array}{l}1.874^{*} \\
(0.081)\end{array}$ & $\begin{array}{r}-1.021^{* * *} \\
(0.293)\end{array}$ & $\begin{array}{r}2.054^{* * *} \\
(0.336)\end{array}$ & $\begin{array}{c}0.389^{* *} \\
(0.131)\end{array}$ & 600 & 0.968 \\
\hline 12 & $\begin{array}{r}2.106 \\
(1.860)\end{array}$ & $\begin{array}{r}1.235 \\
(1.530)\end{array}$ & $\begin{array}{r}-0.501^{* * *} \\
(0.110)\end{array}$ & $\begin{array}{r}0.941^{* * *} \\
(0.284)\end{array}$ & $\begin{array}{c}-0.014 \\
(0.049)\end{array}$ & 600 & 0.978 \\
\hline 13 & $\begin{array}{r}1.197^{* * *} \\
(2.422)\end{array}$ & $\begin{array}{r}1.342^{* * *} \\
(0.773)\end{array}$ & $\begin{array}{r}-1.776^{* * *} \\
(0.152)\end{array}$ & $\begin{array}{r}1.781^{* * *} \\
(0.331)\end{array}$ & $\begin{array}{r}-0.398^{* * *} \\
(0.100)\end{array}$ & 600 & 0.970 \\
\hline 14 & $\begin{array}{r}6.767^{* * *} \\
(1.328)\end{array}$ & $\begin{array}{r}4.790^{* *} \\
(1.570)\end{array}$ & $\begin{array}{r}-1.156^{* * *} \\
(0.181)\end{array}$ & $\begin{array}{r}0.193 \\
(0.285)\end{array}$ & $\begin{array}{r}-0.216^{* *} \\
(0.076)\end{array}$ & 600 & 0.976 \\
\hline 15 & $\begin{array}{r}1.530 \\
(2.626) \\
\end{array}$ & $\begin{array}{r}1.131^{* * *} \\
(0.602) \\
\end{array}$ & $\begin{array}{l}-0.168 \\
(0.112) \\
\end{array}$ & $\begin{array}{r}0.298 \\
(0.313) \\
\end{array}$ & $\begin{array}{r}0.041 \\
(0.055) \\
\end{array}$ & 600 & 0.983 \\
\hline
\end{tabular}

Notes: *, **, *** refer to $10 \%, 5 \%, 1 \%$ significance, respectively, and values in parentheses refer to standard errors; $\alpha_{1}$ refers to relative price coefficient, $\alpha_{2}$ refers to internal demand coefficient, $\alpha_{3}$ refers to relative quality coefficient, $\alpha_{4}$ refers to the EU dummy and $\alpha_{5}$ refers to time effect. 
To check the robustness of our quality proxy, we ran the same regression on Equation (5), replacing our quality proxy with relative patent counts. These patent counts were obtained from the OECD website and supplemented with information from EUKLEMS. These counts report the number of patent citations granted by the European Patent Office (EPO). Tables 6 and 7 report the results for the case of France and Germany, respectively.

Table 6: Results for France (Using Relative Patent Counts as Quality Proxy)

\begin{tabular}{|c|c|c|c|c|c|c|c|}
\hline Industry Code & $\alpha_{1}$ & $\alpha_{2}$ & $\alpha_{3}$ & $\alpha_{4}$ & $\alpha_{5}$ & Obs. & Adjusted $R^{2}$ \\
\hline 1 & $\begin{array}{r}5.715^{* * *} \\
(1.086)\end{array}$ & $\begin{array}{r}1.792^{* * *} \\
(1.208)\end{array}$ & $\begin{array}{r}-0.842^{* * *} \\
(0.099)\end{array}$ & $\begin{array}{r}1.116^{* * *} \\
(0.230)\end{array}$ & $\begin{array}{r}0.374^{* * *} \\
(0.067)\end{array}$ & 600 & 0.973 \\
\hline 2 & $\begin{array}{r}2.278^{* * *} \\
(0.526)\end{array}$ & $\begin{array}{r}1.155^{* * *} \\
(0.641)\end{array}$ & $\begin{array}{c}-0.018 \\
(0.089)\end{array}$ & $\begin{array}{r}1.128^{* * *} \\
(0.324)\end{array}$ & $\begin{array}{c}-0.091 \\
(0.067)\end{array}$ & 594 & 0.975 \\
\hline 3 & $\begin{array}{l}8.525^{* *} \\
(3.026)\end{array}$ & $\begin{array}{r}1.324 \\
(3.813)\end{array}$ & $\begin{array}{c}-0.905^{*} \\
(0.404)\end{array}$ & $\begin{array}{r}3.961^{* * *} \\
(0.850)\end{array}$ & $\begin{array}{c}0.696^{*} \\
(0.286)\end{array}$ & 600 & 0.713 \\
\hline 4 & $\begin{array}{r}4.595^{* * *} \\
(0.940)\end{array}$ & $\begin{array}{r}1.477^{* * *} \\
(0.624)\end{array}$ & $\begin{array}{r}-0.327^{* *} \\
(0.101)\end{array}$ & $\begin{array}{c}0.731^{*} \\
(0.322)\end{array}$ & $\begin{array}{r}0.325^{* * *} \\
(0.081)\end{array}$ & 596 & 0.919 \\
\hline 5 & $\begin{array}{r}1.828^{* * *} \\
(0.030)\end{array}$ & $\begin{array}{r}1.237^{* * *} \\
(0.276)\end{array}$ & $\begin{array}{r}-0.886^{* * *} \\
(0.238)\end{array}$ & $\begin{array}{r}0.471 \\
(0.350)\end{array}$ & $\begin{array}{r}1.206^{* * *} \\
(0.193)\end{array}$ & 600 & 0.972 \\
\hline 6 & $\begin{array}{r}0.153 \\
(1.553)\end{array}$ & $\begin{array}{r}0.604 \\
(1.204)\end{array}$ & $\begin{array}{r}-1.368^{* *} \\
(0.129)\end{array}$ & $\begin{array}{r}0.251 \\
(0.257)\end{array}$ & $\begin{array}{r}0.092 \\
(0.084)\end{array}$ & 600 & 0.982 \\
\hline 7 & $\begin{array}{r}1.351^{* * *} \\
(0.686)\end{array}$ & $\begin{array}{r}3.507^{* * *} \\
(0.489)\end{array}$ & $\begin{array}{r}-1.152 \\
(0.006)\end{array}$ & $\begin{array}{r}0.187 \\
(0.269)\end{array}$ & $\begin{array}{r}0.797^{* * *} \\
(0.143)\end{array}$ & 600 & 0.984 \\
\hline 8 & $\begin{array}{r}1.104 \\
(1.507)\end{array}$ & $\begin{array}{r}1.288 \\
(1.134)\end{array}$ & $\begin{array}{r}-0.581^{* * *} \\
(0.176)\end{array}$ & $\begin{array}{r}0.488 \\
(0.255)\end{array}$ & $\begin{array}{r}0.192 \\
(0.109)\end{array}$ & 600 & 0.988 \\
\hline 9 & $\begin{array}{r}1.085 \\
(0.613)\end{array}$ & $\begin{array}{r}1.279^{* * *} \\
(0.688)\end{array}$ & $\begin{array}{r}-0.573^{* * *} \\
(0.156)\end{array}$ & $\begin{array}{r}0.953^{* * *} \\
(0.231)\end{array}$ & $\begin{array}{c}0.155^{*} \\
(0.065)\end{array}$ & 600 & 0.991 \\
\hline 10 & $\begin{array}{r}4.850^{* * *} \\
(1.447)\end{array}$ & $\begin{array}{r}3.412^{* * *} \\
(0.994)\end{array}$ & $\begin{array}{r}-0.391^{* * *} \\
(0.126)\end{array}$ & $\begin{array}{r}0.404 \\
(0.291)\end{array}$ & $\begin{array}{r}0.355^{* * *} \\
(0.083)\end{array}$ & 600 & 0.985 \\
\hline 11 & $\begin{array}{r}3.920^{* * *} \\
(0.218)\end{array}$ & $\begin{array}{r}1.254^{* * *} \\
(0.013)\end{array}$ & $\begin{array}{r}-0.724^{* * *} \\
(0.238)\end{array}$ & $\begin{array}{r}1.635^{* * *} \\
(0.290)\end{array}$ & $\begin{array}{r}0.748^{* * *} \\
(0.115)\end{array}$ & 600 & 0.972 \\
\hline 12 & $\begin{array}{c}4.012^{*} \\
(1.920)\end{array}$ & $\begin{array}{l}3.700^{*} \\
(1.629)\end{array}$ & $\begin{array}{r}-1.218^{* * *} \\
(0.122)\end{array}$ & $\begin{array}{c}0.516^{*} \\
(0.241)\end{array}$ & $\begin{array}{l}0.290^{*} \\
(0.121)\end{array}$ & 600 & 0.988 \\
\hline 13 & $\begin{array}{r}5.168^{* *} \\
(1.935)\end{array}$ & $\begin{array}{r}2.158 \\
(1.307)\end{array}$ & $\begin{array}{l}-0.228 \\
(0.151)\end{array}$ & $\begin{array}{c}0.770^{* *} \\
(0.274)\end{array}$ & $\begin{array}{c}-0.201^{*} \\
(0.101)\end{array}$ & 600 & 0.976 \\
\hline 14 & $\begin{array}{r}8.587^{* * *} \\
(1.740)\end{array}$ & $\begin{array}{r}2.054^{* * *} \\
(1.687)\end{array}$ & $\begin{array}{r}-0.626^{* *} \\
(0.193)\end{array}$ & $\begin{array}{r}0.322 \\
(0.247)\end{array}$ & $\begin{array}{r}-0.957^{* * *} \\
(0.247)\end{array}$ & 600 & 0.983 \\
\hline 15 & $\begin{array}{r}3.345 \\
(2.220) \\
\end{array}$ & $\begin{array}{c}1.685^{*} \\
(0.970)\end{array}$ & $\begin{array}{l}-0.371 \\
(0.160) \\
\end{array}$ & $\begin{array}{c}0.869^{*} \\
(0.242)\end{array}$ & $\begin{array}{l}-0.002 \\
(0.089)\end{array}$ & 600 & 0.991 \\
\hline
\end{tabular}

Notes: ${ }^{*},{ }^{* *},{ }^{* * *}$ refer to $10 \%, 5 \%, 1 \%$ significance, respectively, and values in parentheses refer to standard errors; $\alpha_{1}$ refers to relative price coefficient, $\alpha_{2}$ refers to internal demand coefficient, $\alpha_{3}$ refers to relative quality coefficient, $\alpha_{4}$ refers to the EU dummy and $\alpha_{5}$ refers to time effect. 
Table 7: Results for Germany (Using Relative Patent Counts as Quality Proxy)

\begin{tabular}{|c|c|c|c|c|c|c|c|}
\hline Industry Code & $\alpha_{1}$ & $\alpha_{2}$ & $\alpha_{3}$ & $\alpha_{4}$ & $\alpha_{5}$ & Obs. & Adjusted $R^{2}$ \\
\hline 1 & $\begin{array}{r}8.458^{* * *} \\
(1.367)\end{array}$ & $\begin{array}{r}1.137^{* * *} \\
(0.728)\end{array}$ & $\begin{array}{r}-1.154^{* * *} \\
(0.108)\end{array}$ & $\begin{array}{r}0.953^{* * *} \\
(0.231)\end{array}$ & $\begin{array}{r}0.416^{* * *} \\
(0.061)\end{array}$ & 600 & 0.973 \\
\hline 2 & $\begin{array}{r}3.481^{* * *} \\
(0.416)\end{array}$ & $\begin{array}{r}1.362^{* * *} \\
(0.360)\end{array}$ & $\begin{array}{l}-0.072 \\
(0.060)\end{array}$ & $\begin{array}{r}0.404 \\
(0.291)\end{array}$ & $\begin{array}{r}0.156^{* * *} \\
(0.035)\end{array}$ & 594 & 0.975 \\
\hline 3 & $\begin{array}{r}3.827 \\
(3.747)\end{array}$ & $\begin{array}{r}1.539 \\
(5.568)\end{array}$ & $\begin{array}{l}-0.228 \\
(0.399)\end{array}$ & $\begin{array}{r}1.635^{* * *} \\
(0.290)\end{array}$ & $\begin{array}{r}0.300 \\
(0.331)\end{array}$ & 600 & 0.713 \\
\hline 4 & $\begin{array}{r}1.927^{* * *} \\
(0.354)\end{array}$ & $\begin{array}{r}0.572 \\
(0.824)\end{array}$ & $\begin{array}{r}-0.415^{* *} \\
(0.128)\end{array}$ & $\begin{array}{r}0.488 \\
(0.255)\end{array}$ & $\begin{array}{r}0.486^{* * *} \\
(0.105)\end{array}$ & 596 & 0.919 \\
\hline 5 & $\begin{array}{r}1.552^{* * *} \\
(0.289)\end{array}$ & $\begin{array}{r}1.612^{* * *} \\
(0.156)\end{array}$ & $\begin{array}{r}-0.869^{* * *} \\
(0.193)\end{array}$ & $\begin{array}{c}0.516^{*} \\
(0.241)\end{array}$ & $\begin{array}{r}0.738^{* * *} \\
(0.137)\end{array}$ & 600 & 0.972 \\
\hline 6 & $\begin{array}{l}2.788^{*} \\
(1.348)\end{array}$ & $\begin{array}{l}1.814^{*} \\
(0.917)\end{array}$ & $\begin{array}{r}-0.520^{* * *} \\
(0.099)\end{array}$ & $\begin{array}{l}0.770^{* *} \\
(0.274)\end{array}$ & $\begin{array}{c}0.134^{* *} \\
(0.045)\end{array}$ & 600 & 0.982 \\
\hline 7 & $\begin{array}{l}3.026^{*} \\
(1.281)\end{array}$ & $\begin{array}{l}3.050^{*} \\
(1.272)\end{array}$ & $\begin{array}{r}-0.338^{* *} \\
(0.130)\end{array}$ & $\begin{array}{r}1.116^{* * *} \\
(0.230)\end{array}$ & $\begin{array}{r}0.289^{* * *} \\
(0.075)\end{array}$ & 600 & 0.984 \\
\hline 8 & $\begin{array}{l}2.338^{*} \\
(1.003)\end{array}$ & $\begin{array}{r}0.941 \\
(0.933) \\
\end{array}$ & $\begin{array}{r}-0.714^{* * *} \\
(0.147)\end{array}$ & $\begin{array}{r}1.128^{* * *} \\
(0.324)\end{array}$ & $\begin{array}{l}-0.007 \\
(0.048)\end{array}$ & 600 & 0.988 \\
\hline 9 & $\begin{array}{r}2.989^{* * *} \\
(0.479)\end{array}$ & $\begin{array}{r}0.687 \\
(0.826)\end{array}$ & $\begin{array}{l}-1.118^{*} \\
(0.826)\end{array}$ & $\begin{array}{r}3.961^{* * *} \\
(0.850)\end{array}$ & $\begin{array}{r}0.020 \\
(0.049)\end{array}$ & 600 & 0.991 \\
\hline 10 & $\begin{array}{r}3.363^{* *} \\
(1.116)\end{array}$ & $\begin{array}{r}1.373 \\
(0.807)\end{array}$ & $\begin{array}{r}-1.031^{* * *} \\
(0.093)\end{array}$ & $\begin{array}{r}0.032 \\
(0.247)\end{array}$ & $\begin{array}{r}0.208^{* * *} \\
(0.063)\end{array}$ & 600 & 0.985 \\
\hline 11 & $\begin{array}{r}1.041^{* * *} \\
(0.247)\end{array}$ & $\begin{array}{r}1.639^{* * *} \\
(0.275)\end{array}$ & $\begin{array}{r}-0.817^{* *} \\
(0.260)\end{array}$ & $\begin{array}{r}0.087 \\
(0.242) \\
\end{array}$ & $\begin{array}{r}0.463^{* * *} \\
(0.094)\end{array}$ & 600 & 0.972 \\
\hline 12 & $\begin{array}{r}1.188 \\
(1.126)\end{array}$ & $\begin{array}{r}1.134 \\
(1.072)\end{array}$ & $\begin{array}{r}-0.522^{* * *} \\
(0.090)\end{array}$ & $\begin{array}{r}0.471 \\
(0.350)\end{array}$ & $\begin{array}{r}0.035 \\
(0.032)\end{array}$ & 600 & 0.988 \\
\hline 13 & $\begin{array}{r}1.449^{* * *} \\
(0.091)\end{array}$ & $\begin{array}{r}4.499^{* *} \\
(1.456)\end{array}$ & $\begin{array}{r}-1.121^{* * *} \\
(0.138)\end{array}$ & $\begin{array}{r}0.251 \\
(0.257)\end{array}$ & $\begin{array}{c}0.223^{* *} \\
(0.080)\end{array}$ & 600 & 0.976 \\
\hline 14 & $\begin{array}{r}6.786^{* * *} \\
(1.115)\end{array}$ & $\begin{array}{r}4.796^{* * *} \\
(1.376)\end{array}$ & $\begin{array}{r}-1.022^{* * *} \\
(0.162)\end{array}$ & $\begin{array}{c}0.731^{*} \\
(0.322)\end{array}$ & $\begin{array}{r}0.217^{* * *} \\
(0.322)\end{array}$ & 600 & 0.983 \\
\hline 15 & $\begin{array}{l}1.410^{*} \\
(0.896)\end{array}$ & $\begin{array}{r}1.380^{* * *} \\
(0.399)\end{array}$ & $\begin{array}{l}-0.139 \\
(0.399)\end{array}$ & $\begin{array}{r}0.187 \\
(0.269)\end{array}$ & $\begin{array}{r}0.187 \\
(0.269)\end{array}$ & 600 & 0.991 \\
\hline
\end{tabular}

Notes: ${ }^{*},{ }^{* *},{ }^{* * *}$ refer to $10 \%, 5 \%, 1 \%$ significance, respectively, and values in parentheses refer to standard errors; $\alpha_{1}$ refers to relative price coefficient, $\alpha_{2}$ refers to internal demand coefficient, $\alpha_{3}$ refers to relative quality coefficient, $\alpha_{4}$ refers to the EU dummy and $\alpha_{5}$ refers to time effect.

In general, based on the results of Tables 4 to 7 , we observe that innovation efforts aimed at improving technological know-how and product quality (though R\&D intensity and patent counts) are important determinants of import demand. The quality elasticity proxied by R\&D intensity reports highly significant values ranging from 0.2 to 1.8 percent. This means that increasing the domestic innovation efforts by 1 percent, in contrast to those by foreign competitors 
results in an increase in the demand for local products and hence a reduction in the demand for foreign goods by 0.2 to 1.8 percent in the importer country.

Higher quality elasticities (in absolute terms) using R\&D intensity are recorded in industries like Basic Metals (1.636), Food, Drink and Tobacco (0.766) and Leather and Footwear (1.645) in France and in industries like Basic Metals (0.866), Machinery (0.713), Electrical Equipment (1.191), Transport Equipment (0.872), Paper Products (1.776) and Rubber and Plastic (1.156) in Germany. Similarly, quality elasticities using patent counts follow the same trend wherein higher quality elasticities are recorded in the same industries, namely Basic Metals (0.886), Food, Drink and Tobacco (0.724) and Leather and Footwear (1.218) in France and in Basic Metals (0.869), Machinery (0.714), Electrical Equipment (1.118), Transport Equipment (1.031), Paper Products (1.121) and Rubber and Plastic (1.022) in Germany.

Price elasticities are, generally, much larger in magnitude compared to quality elasticities, suggesting the greater importance of prices in affecting consumer import demand. The price elasticities tend to be higher in industries producing homogeneous goods and lower in industries producing differentiated goods. For instance, the price elasticity in Agriculture is relatively high (5.970 in France and 6.899 in Germany) whereas price elasticity in Machinery is relatively low (0.84 in France and 0.166 in Germany). Overall, the results displayed in Tables 6 and 7 are similar to those seen in Tables 4 and 5, thus, increasing our credibility of the use of $R \& D$ intensity calculated with $R \& D$ expenditures reported in Product Field.

Table 8, below, collates the results from Tables 4 and 5 so as to compare the relative product performance of France and Germany when faced with outside competition. 
Table 8: Comparison of Relative Price and Quality (Using R\&D Intensity as Proxy) Elasticities Between France and Germany

\begin{tabular}{|c|c|c|c|c|}
\hline Industry & $\alpha_{1}^{\text {France }}$ & $\left|\alpha_{3}^{\text {France }}\right|$ & $\alpha_{1}^{\text {Germany }}$ & $\left|\alpha_{3}^{\text {Gemany }}\right|$ \\
\hline Agriculture & $\begin{array}{r}5.970^{* * *} \\
(1.237)\end{array}$ & $\begin{array}{r}0.850^{* * *} \\
(0.102)\end{array}$ & $\begin{array}{r}6.899^{* * *} \\
(1.537)\end{array}$ & $\begin{array}{r}1.071^{* * *} \\
(0.106)\end{array}$ \\
\hline Basic Metals & $\begin{array}{r}0.159^{* * *} \\
(0.038)\end{array}$ & $\begin{array}{r}1.636^{* * *} \\
(0.239)\end{array}$ & $\begin{array}{r}1.872^{* * *} \\
(0.935)\end{array}$ & $\begin{array}{r}0.866^{* * *} \\
(0.227)\end{array}$ \\
\hline $\begin{array}{l}\text { Non-Metallic } \\
\text { Mineral }\end{array}$ & $\begin{array}{r}4.136^{* * *} \\
(1.940)\end{array}$ & $\begin{array}{r}1.018^{* * *} \\
(0.123)\end{array}$ & $\begin{array}{c}5.175^{*} \\
(2.363)\end{array}$ & $\begin{array}{r}0.589^{* * *} \\
(0.121)\end{array}$ \\
\hline Chemicals & $\begin{array}{r}3.801^{* * *} \\
(1.937)\end{array}$ & $\begin{array}{r}0.481^{* * *} \\
(0.156)\end{array}$ & $\begin{array}{r}2.251 \\
(1.662)\end{array}$ & $\begin{array}{r}0.244 \\
(0.152)\end{array}$ \\
\hline Machinery & $\begin{array}{r}0.84 \\
(1.474) \\
\end{array}$ & $\begin{array}{r}0.557^{* * *} \\
(0.162)\end{array}$ & $\begin{array}{r}0.166 \\
(1.684)\end{array}$ & $\begin{array}{r}0.713^{* * *} \\
(0.162)\end{array}$ \\
\hline $\begin{array}{l}\text { Electrical } \\
\text { Equipment }\end{array}$ & $\begin{array}{r}3.716^{* * *} \\
(0.645)\end{array}$ & $\begin{array}{r}0.625^{* * *} \\
(0.140)\end{array}$ & $\begin{array}{c}2.164^{* *} \\
(0.776)\end{array}$ & $\begin{array}{r}1.191^{* * *} \\
(0.140)\end{array}$ \\
\hline $\begin{array}{l}\text { Transport } \\
\text { Equipment }\end{array}$ & $\begin{array}{r}9.163^{* * *} \\
(2.866)\end{array}$ & $\begin{array}{r}0.387 \\
(0.241)\end{array}$ & $\begin{array}{c}6.467^{* *} \\
(1.999)\end{array}$ & $\begin{array}{r}0.872^{* * *} \\
(0.115)\end{array}$ \\
\hline $\begin{array}{l}\text { Food, Drink, } \\
\text { Tobacco }\end{array}$ & $\begin{array}{r}3.585 \\
(2.124)\end{array}$ & $\begin{array}{r}0.766^{* *} \\
(0.116)\end{array}$ & $\begin{array}{c}8.096^{*} \\
(3.586)\end{array}$ & $\begin{array}{r}1.021^{* * *} \\
(0.293)\end{array}$ \\
\hline $\begin{array}{l}\text { Leather \& } \\
\text { Footwear }\end{array}$ & $\begin{array}{r}2.564^{* * *} \\
(0.222)\end{array}$ & $\begin{array}{r}1.645^{* * *} \\
(0.154)\end{array}$ & $\begin{array}{r}2.106 \\
(1.860)\end{array}$ & $\begin{array}{r}0.501^{* * *} \\
(0.110)\end{array}$ \\
\hline Paper Prod & $\begin{array}{r}7.775^{* * *} \\
(1.953)\end{array}$ & $\begin{array}{r}0.474^{* * *} \\
(0.188)\end{array}$ & $\begin{array}{r}1.197^{* * *} \\
(2.422)\end{array}$ & $\begin{array}{r}1.776^{* * *} \\
(0.152)\end{array}$ \\
\hline Rubber \& Plastic & $\begin{array}{l}3.843^{*} \\
(2.148)\end{array}$ & $\begin{array}{r}0.400^{* *} \\
(0.149)\end{array}$ & $\begin{array}{r}6.767^{* * *} \\
(1.328)\end{array}$ & $\begin{array}{r}1.156^{* * *} \\
(0.181)\end{array}$ \\
\hline Other Manu & $\begin{array}{r}9.163^{* * *} \\
(2.866)\end{array}$ & $\begin{array}{r}0.387 \\
(0.241)\end{array}$ & $\begin{array}{r}1.530 \\
(2.626) \\
\end{array}$ & $\begin{array}{r}0.168 \\
(0.112) \\
\end{array}$ \\
\hline
\end{tabular}

Notes: ${ }^{*},{ }^{* *},{ }^{* * *}$ refer to $10 \%, 5 \%, 1 \%$ significance, respectively, and values in parentheses refer to standard errors; $\alpha_{1}$ refers to relative price coefficient and $\alpha_{3}$ refers to relative quality coefficient (in absolute terms).

Table 8 allows us to compare the substitutability of German and French goods vis-à-vis their foreign competitors. We note that price elasticities of most industries in Germany are relatively lower than those in France. This means that for a 1 percent increase in domestic product prices relative to import prices, the increase in import demand in Germany is lower than that in France. This implies that German products are much more differentiated than those of its exporting competitors. As such, Germany is able to resist competition coming from similar products of foreign origins despite these products being cheaper than their foreign counterparts. In contrast, French products are not able to withstand competition from their foreign counterparts as their products tend to 
be more substitutable. This result corresponds to the economic literature on the loss of French price competitiveness as seen in Section 2.

When we compare the quality elasticities between these two countries in Table 8 , we observe that the quality coefficients are very similar across the countries in magnitude though the elasticities for Germany are slightly higher than those for France. This is particularly true in industries producing highly differentiated products like Machinery, Transport Equipment, Electrical Equipment, Paper Products and Rubber and Plastic. In industries that produce highly substitutable goods, the impact of quality improvement in domestic goods is relatively similar in France and in Germany. For instance, an increase in domestic product quality on Agriculture decreases import demand in France by 0.85 and by 1.071 percent in Germany whereas the same increase in domestic product quality in Electrical Equipment decreases import demand in France by 0.625 and by 1.191 percent in Germany.

Tables 9 and 10 decompose the effect of each variable namely prices, internal demand and quality in affecting import growth throughout the period of our study (1991 to 2010). This decomposition effect is very similar to the Constant Market Shares Analysis and is obtained by multiplying the coefficients with the average growth of each variable throughout the period. We, thus, look at how much of growth in imports is explained by an improvement in relative import prices (resulting from either an increase in domestic price or a decrease in the import price), an increase in internal demand and an improvement in relative import quality (due to either an increase in import quality or a decrease in domestic quality) ${ }^{12}$.

12 To calculate the contribution of relative price (or quality) growth on import growth during this period, we first define the relative price, quality and demand for Germany (or France). For that, we take the weighted average of relative price, R\&D intensity and demand for Germany (or France), using the bilateral import of each importer relative to total imports to Germany (or France) as weights. Next, we calculate the average growth rate of relative prices, R\&D intensity and demand. Finally, we multiply the growth rates with the coefficients found in Tables 4 for France and Table 5 for Germany. Import growth is hence explained by the sum of each of these effects. Table 9 and Table 10 also report the share of each effect in contributing to overall import growth in parentheses. 
Table 9: Decomposition of Factors Contributing to Average Import Growth in France for Period 1991 to 2010

\begin{tabular}{c|c|c|c:c}
\hline Industry Code & Import Growth & Price Effect & Demand Effect & Quality Effect \\
\hline 1 & +5.527 & +3.372 & +3.055 & -0.244 \\
\hline 5 & +7.733 & +0.038 & +1.135 & +0.029 \\
\hline 6 & +5.955 & +1.048 & +0.132 & -0.033 \\
\hline 7 & +9.238 & +1.493 & +2.184 & +0.078 \\
\hline 8 & +6.665 & +0.419 & +0.583 & +0.026 \\
\hline 9 & +6.632 & +2.251 & +4.748 & +0.027 \\
\hline 10 & +7.603 & +0.142 & +2.057 & -0.189 \\
\hline 11 & +6.644 & +3.024 & +1.732 & +0.092 \\
\hline 12 & +5.556 & +2.033 & +2.035 & +0.193 \\
\hline 13 & +6.025 & +1.103 & +0.592 & -0.077 \\
\hline 14 & +7.355 & +6.351 & +1.202 & +0.162 \\
\hline 15 & +10.007 & +0.342 & +1.137 & +0.322 \\
\hline
\end{tabular}

Source: Author's own calculation.

From Table 9, we observe that the growth in French import demand is largely fuelled by the price effect and the demand effect. We notice that all price effects are positive, implying that import growth is attributed to an improvement in the relative import price of the product resulting from either a decrease in import prices or an increase in domestic prices. This further supports the economic literature which attributes the loss of French competitiveness to a loss in price competition (higher French costs of production and hence higher prices of French products). We notice positive quality effects in most sectors which imply that French import growth is also a result of improved import quality (or a deterioration of French product quality). A negative quality effect signals a fall in imports due to an improvement in relative product quality attributed to either an improvement in domestic product quality or a deterioration of foreign import quality. Only 4 industries (Agriculture, Non-metallic Mineral Products, Transport Equipment and Paper Products) withstand foreign competition when competing in terms of product quality. In all other industries, the quality effect is positive though small, suggesting a loss in French competitiveness in terms of quality competition, on top of price competition. 
Table 10: Decomposition of Factors Contributing to Average Import Growth in Germany for Period 1991 to 2010

\begin{tabular}{c|c|c|c|c}
\hline Industry Code & Import Growth & Price Effect & Demand Effect & Quality Effect \\
\hline 1 & +4.611 & +2.351 & +0.989 & +0.660 \\
\hline 5 & +7.951 & +0.316 & +0.943 & +0.010 \\
\hline 6 & +4.671 & +2.463 & +2.259 & -0.200 \\
\hline 7 & +10.376 & +0.304 & +1.089 & +0.050 \\
\hline 8 & +6.103 & +0.018 & +0.882 & -0.261 \\
\hline 9 & +6.448 & +0.231 & +2.091 & -0.389 \\
\hline 10 & +6.161 & +0.964 & +2.811 & -0.235 \\
\hline 11 & +5.942 & +1.179 & +0.986 & -0.523 \\
\hline 12 & +2.788 & +1.401 & +1.200 & -0.345 \\
\hline 13 & +5.583 & +0.345 & +0.874 & -0.333 \\
14 & +6.810 & +0.811 & +2.984 & -0.530 \\
\hline 15 & +8.071 & +0.256 & +1.119 & +0.111 \\
\hline
\end{tabular}

Source: Author's own calculation.

Similar to Table 9, Table 10 shows a breakdown of growth in German import demand originating from both price and demand effects. Price effect is dominantly positive, reflecting an improvement in the relative import price while quality effect is dominantly negative in Germany, suggesting that Germany is better able to resist foreign competition by competing in terms of quality. Import demand has fallen when the competition is in terms of quality as seen from the various negative quality effects, particularly present in industries producing highly differentiated goods. To better compare which effect price or quality effect better explains import growth, we consider Table 11 which shows the share of contribution of each of the two effects (in percent) towards a 1 percent increase in import growth. 
Table 11: Share of Contribution of Price and Quality Effect on 1 Percent Import Growth Between France and Germany

\begin{tabular}{l|c|c|c|c}
\hline \multirow{2}{*}{ Industry } & \multicolumn{2}{|c|}{ France } & \multicolumn{2}{c}{ Germany } \\
\cline { 2 - 4 } & Price Effect & Quality Effect & Price Effect & Quality Effect \\
\hline Agriculture & +0.610 & -0.044 & +0.510 & +0.143 \\
Basic Metals & +0.005 & +0.004 & +0.040 & +0.002 \\
\hline Non-Metallic Mineral & +0.176 & -0.005 & +0.527 & -0.043 \\
\hline Chemicals & +0.162 & +0.008 & +0.029 & +0.005 \\
\hline Machinery & +0.063 & +0.004 & +0.003 & -0.043 \\
\hline Electrical Equipment & +0.339 & +0.004 & +0.036 & -0.060 \\
\hline Transport Equipment & +0.019 & -0.025 & +0.156 & -0.038 \\
\hline Food, Drink, Tobacco & +0.455 & +0.014 & +0.198 & -0.088 \\
\hline Leather \& Footwear & +0.366 & +0.035 & +0.502 & -0.124 \\
\hline Paper Prod & +0.183 & -0.013 & +0.062 & -0.060 \\
\hline Rubber \& Plastic & +0.863 & +0.022 & +0.119 & -0.078 \\
\hline Other Manu & +0.034 & +0.032 & +0.032 & +0.014 \\
\hline
\end{tabular}

Source: Author's own calculation.

Table 11 allows us to compare the relative strength of price and quality effects across France and Germany in resisting foreign competition. We notice that the price effect is larger in magnitude compared to the quality effect in both countries, suggesting that price competition remains an important component in determining imports in both countries. In particular, French products seem more substitutable to imports compared to German products since the price effect in France is higher than German price effects in most sectors with the exception of Basic Metals, Non-Metallic Minerals, Transport Equipment and Leather and Footwear. When it comes to quality competition, Germany performs better than France in most industries namely Basic Metals, Chemicals, Machinery, Electrical Equipment and Other Manufactures. An improvement (and/or deterioration of import quality) in German product quality has a larger decrease in import demand in favor of domestic product than in France. Thus, Germany is better able to resist foreign competition when competing in terms of quality. 
Our results from this section show that price competition remains an important determinant in contributing towards import growth. French products tend to be highly substitutable vis-à-vis their foreign counterparts compared to German products. This increased substitutability of French products explains, to some extent, the loss of French competitiveness in recent years. In order to better resist foreign competition and hence reduce imports in favor of domestic consumption, both countries need to compete by offering cheaper products. France appears to be more capable (than Germany) in resisting foreign competition through price competition in selected sectors. In contrast, Germany appears to have a stronghold on resisting foreign competition through quality competition compared to France.

\section{Discussion and Conclusion}

Our results from Section 5 point to the loss of French competitiveness in terms of price competition and to better quality competition on the part of Germany. This has been attested and studied in many research papers. Our paper contributes to this group of literature by offering an alternative way to look at the question of French versus German competitiveness. Instead of considering French and German exports, we look at how well these countries perform in their own domestic markets when faced with external competition. Our results seem to parallel the results in other studies which increases our credibility.

In addition, our paper tries to improve econometric methodology related to the estimation of long-run price and quality elasticities. Most studies have calculated biased price elasticities as a result of ignoring the impact of quality in the econometric specification and as a result of weak econometric specification when dealing with price endogeneity. Our paper proposes a way to eliminate these problems by allowing for quality effects in our model (Section 3) and by using 2SLS methodology to eliminate the problem of price endogeneity. We use unitary costs of production (which is made up of unit labor costs, costs of capital 
and costs of intermediate goods), mark-up and bilateral distance as instrumental variables of product prices. These instruments are not traditional instruments and require more justification and research to be validated. They have been chosen because they are strongly correlated to product prices (Ragacs, Resch and Vondra, 2011). Nevertheless, the Sargan test results (Section 4) show that the instruments proposed in our study are valid and our results serve to improve the estimation of price elasticities. Our long-run elasticities conform to elasticities estimated in other studies, further promoting our econometric methodology. More research is needed to further explore other possible instruments in order to eliminate the price endogeneity problem in trade studies.

Our paper also revisits the use of innovation efforts to proxy product quality. We use R\&D intensity, reported in Product Field as a proxy for product quality. R\&D expenditures reported in Product Field better define the technological process related to improving product quality than R\&D expenditures reported in Main Activity since these expenditures under-report 'true' expenditures spent in a particular industry. Nevertheless, the use of $R \& D$ to represent product quality remains very narrow. This is because product quality depends on different factors such as the image of the firm or of the country and consumer perceptions. In addition, $\mathrm{R} \& \mathrm{D}$ has a negative impact on production costs (by improving the production process and hence reducing the price of products). This channel has not been widely visited in the economic literature and remains a challenging task in current trade studies. Indeed, using a quality indicator based on consumer surveys or innovation surveys may be a technique to capture a wider scope of product quality as compared to R\&D expenditures. Nevertheless, R\&D expenditures remain an attractive alternative as they are widely available and their use has been credited by numerous other studies in this field. In addition, a robustness test was conducted using a number of patent counts as a proxy for product quality. The patent counts were calculated based on citations made by countries that re-use patents that were directed at improving only product quality and not production processes. The regression results using this alternative 
proxy (Tables 6 and 7) provided similar results, leading us to validate the use of our improved R\&D intensity variable as a bonfide proxy for product quality. Again, more research is necessary to explore the various channels in which $R \& D$ efforts can improve product quality and this is also where our future research is headed (Thanagopal, 2014; Thanagopal and Housset, 2014).

In conclusion, this paper compares the ability of France and Germany in resisting foreign competition by making their products less substitutable and highly differentiated (and of a higher quality). The relative price coefficients arising from our regressions imply that French products may be highly substitutable vis-à-vis its foreign competitors as opposed to German products. A comparison of relative price and relative quality coefficients implies that German products (especially in sectors producing highly differentiated products) employ better competitive practices than French products since they tend to be less substitutable and highly differentiated vis-à-vis their foreign counterparts. These results may be useful to policy-makers since our results help to characterize the strengths of the sectors in terms of price and quality competition. In this way, policy-makers may use these coefficients to target pricing and innovation strategies so as to make their products less substitutable and highly differentiable. 


\section{Appendix}

In order to eliminate the underestimation bias when using $R \& D$ expenditures reported under Main Activity, we convert these R\&D expenditures to expenditures reported under Product Field. In this way, we are able to account for the 'true' $\mathrm{R} \& \mathrm{D}$ spending in each sector which is the closest proxy that accounts for product quality. This work was performed by our colleague Gabriel Galand together with Thannaletchimy Thanagopal as part of SEURECO working report (Galand and Thanagopal, 2013).

We rely primarily on R\&D expenditures obtained from the OECD STAN database which provides $R \& D$ expenditures reported under Main Activity for all the countries in our sample. In addition, the database also provides $R \& D$ expenditures reported under Product Field for an ensemble of 6 countries namely Belgium, Denmark, Finland, France, the United Kingdom and Sweden. Thus, we try to estimate the bias involved in using data reported in Main Activity rather than in Product Field.

Since the $R \& D$ expenditures reported in Main Activity only report spending of an enterprise relevant to the industry, secondary expenditures from these industries are not reported in the 'correct' industries, but are instead recorded under the service industry as non-market services. Our aim is to determine the reallocation of these secondary spending to the proper corresponding industries so as to correct the underestimation bias in R\&D expenditures reported in Main Activity.

Using the small sample of 6 countries, we ran a linear regression to estimate the correlation between the $\mathrm{R} \& \mathrm{D}$ expenditures recorded under non-market services and the underestimation bias in reporting R\&D expenditures in Main Activity rather than in Product Field.

Bias $=-0.0508+0.809 * R \& D$ in non-market services 
Given this correlation, we are able to determine the proportion of this bias to its original source industry. The proportions are provided in Table A1 below.

Table A1: Distribution Proportions

\begin{tabular}{|c|c|}
\hline Industry Code & Distribution Proportion \\
\hline 1 & 0.0360 \\
\hline 2 & 0.0000 \\
\hline 3 & 0.0360 \\
\hline 4 & 0.0360 \\
\hline 5 & 0.0360 \\
\hline 6 & 0.0070 \\
\hline 7 & 0.5080 \\
\hline 8 & 0.0000 \\
\hline 9 & 0.1420 \\
\hline 10 & 0.0990 \\
\hline 11 & 0.0360 \\
\hline 12 & 0.0000 \\
\hline 13 & 0.0070 \\
\hline 14 & 0.0360 \\
\hline 15 & 0.0070 \\
\hline
\end{tabular}

The interpretation of the above results is as follows. For example, we should redistribute 3.6 percent of the bias towards industry 14 which is the original source industry. Hence, using the correlation equation, we are able to calculate the amount of bias for the remaining countries in our sample and then we determine the amounts to be redistributed to each source industry using the estimated distribution proportions. In this way, we correct for the underestimation bias in R\&D reported in Main Activity. 


\section{Literature}

Anderton, Bob, 1999, "Innovation, product quality, variety and trade performance: an empirical analysis of Germany and the UK", Oxford Economic Papers, 51(1), pp. 152-167. http://dx.doi.org/10.1093/oep/51.1.152

Artus, Patrick and Lionel Fontagné, 2006, Evolution Récente du Commerce Extérieur Français, Paris: Conseil d'Analyse Économique, http://www.diplomatie. gouv.fr/fr/IMG/pdf/commercexterieur.pdf (accessed January 20, 2013).

Bureau of Labor Statistics, 2013, "International Labor Comparisons" (ILC), http://www.bls.gov/fls/ (accessed January 20, 2013).

Carone, Giuseppe, 1996, "Modeling the U.S. Demand for Imports through Cointegration and Error Correction", Journal of Policy Modeling, 18(1), pp. 1-48. http://dx.doi.org/10.1016/0161-8938(95)00058-5

Chang, Tsangyao, Yuan-Hong Ho and Chiung-Ju Huang, 2005, "A Reexamination of South Korea's Aggregate Import Demand Function: The Bounds Test Analysis", Journal of Economic Development, 30(1), pp. 119-128, http://www.jed.or.kr/full-text/30-1/09_J683.PDF (accessed January 20, 2013).

CEPII, 2013a, "Comptes Harmonisés sur les Echanges et L'Economie Mondiale (CHELEM)", http://www.cepii.fr/CEPII/en/bdd_modele/presentation.asp?id=17 (accessed January 28, 2012).

CEPII, 2013b, "GeoDist", http://www.cepii.fr/CEPII/en/bdd_modele/ presentation.. sp?id=6 (accessed January 20, 2013).

Crozet, Mathieu and Hélène Erkel-Rousse, 2004, "Trade Performances, Product Quality Perceptions, and the Estimation of Trade Price Elasticities", Review of International Economics, 12(1), pp. 108-129. http://dx.doi.org/10.1111/j.14679396.2004.00434.x

Crozet, Mathieu, Keith Head and Thierry Mayer, 2011, "Quality Sorting and Trade: Firm-level Evidence for French Wine”, Review of Economic Studies, 79(2), pp. 609-644. http://dx.doi.org/10.1093/restud/rdr030 
Didier, Michel and Gilles Koléda, 2011, Compétitivité France Allemagne, Le Grand Écart, Paris: Economica/Coe-Rexecode.

Eaton, Jonathan and Samuel Kortum, 2002, "Technology, Geography and Trade", Econometrica, 70(5), pp. 1741-1779. http://dx.doi.org/10.1111/14680262.00352

ECB, Task Force of Monetary Policy Committee of the European System of Central Banks, 2005, "Competitiveness and the Export Performance of the Euro Area”, European Central Bank Occasional Paper Series, No. 30, Frankfurt: ECB, http://www.ecb.europa.eu/pub/pdf/scpops/ecbocp30.pdf (accessed January 20, 2013).

Erkel-Rousse, Hélène and Daniel Mirza, 2002, "Import price elasticities: reconsidering the evidence", Canadian Journal of Economics, 35(2), pp. 282-306. http://dx.doi.org/10.1111/1540-5982.00131

EUKLEMS, 2010, "Patents", http://www.euklems.net/ (accessed January 20, 2013).

Fieler, Ana Cecília, 2011, "Quality Differentiation in Trade: Theory and Evidence", manuscript, Department of Economics, Philadelphia, PA: University of Pennsylvania, http://www.maxwell.syr.edu/uploadedFiles/econ/seminars/ Fieler\%20-\%20Quality\%20Differentiation.pdf (accessed January 20, 2013).

Fontagné, Lionel and Guillaume Gaulier, 2008, Performances à l'Exportation de la France et de l'Allemagne, Paris: Conseil d'Analyse Économique, http://www. cae-eco.fr/IMG/pdf/081aa.pdf (accessed January 30, 2013).

Fontagné, Lionel, Guillaume Gaulier and Soledad Zignago, 2007, "Specialization Across Varieties and North-South Competition”, Economic Policy, 23(53), pp. 5191. http://dx.doi.org/10.1111/j.1468-0327.2007.00193.x

Galand, Gabriel and Thannaletchimy Thanagopal, 2013, "Nouvelles Estimations 2013 pour le modélè NEMESIS", SEURECO Working Paper, No. 3, March, Paris: SEURECO, http://erasme-team.eu (forthcoming). 
Hallak, Juan Carlos, 2006, "Product quality and the direction of trade", Journal of International Economics, 68(1), pp. 238-265. http://dx.doi.org/10.1016/j. jinteco.2005.04.001

Hallak, Juan Carlos and Peter Schott, 2011, "Estimating Cross-Country Differences in Product Quality", The Quarterly Journal of Economics, 126(1), pp. 417-474. http://dx.doi.org/10.1093/qje/qjq003

Hamori, Shigeyuki and Yoichi Matsubayashi, 2001, "An empirical analysis on the stability of Japan's aggregate import demand function", Japan and the World Economy, 13(2), pp. 135-144. http://dx.doi.org/10.1016/s0922-1425(00)00063-3

Ioannidis, Evangelos and Paul Schreyer, 1997, “Technology and Non-Technology Determinants of Export Market Share Growth”, OECD Economic Studies, 28(1), pp. 170-204, http://www.oecd.org/eco/growth/2733930.pdf (accessed January 20, 2013).

Johnson, Harry, 1964, "Review of An Essay on Trade and Transformation by Staffan Burenstam Linder", Economica, 31(121), pp. 86-90. http://dx.doi. org/10.2307/2550929

Khandelwal, Amit, 2010, “The Long and Short (of) Quality Ladders", Review of Economic Studies, 77(4), pp. 1450-1476. http://dx.doi.org/10.1111/j.1467937X.2010.00602.x

Krugman, Paul, 1979, "Increasing Returns, Monopolistic Competition, and International Trade", Journal of International Economics, 9(4), pp. 469-479. http://dx.doi.org/10.1016/0022-1996(79)90017-5

Mayer, Thierry and Soledad Zignago, 2011, "Notes on CEPII'S distances measures: The GeoDist Database", CEPII Working Paper, No. 25, Paris: CEPII, http://www.cepii.fr/PDF_PUB/wp/2011/wp2011-25.pdf (accessed January 30, 2013).

OECD, 2013, “STAN", http://stats.oecd.org (accessed January 30, 2013). 
Oliveira-Martins, Joacquim, Stefano Scarpetta and Dirk Pilat, 1996, "Mark-up Pricing, Market Structure and the Business Cycle", OECD Economic Studies, 27(2), pp. 72-105, http://www.oecd.org/eco/growth/17981306.pdf (accessed January 30, 2013).

Ragacs, Christian, Beate Resch and Klaus Vondra, 2011, "Austria's Manufacturing Competitiveness", Monetary Policy and the Economy, 0(3), pp. 35-61, http:// www.oenb.at/dms/oenb/Publikationen/Volkswirtschaft/Monetary-Policyand-the-Economy/2011/Monetary-Policy-and-the-Economy-Q3-11/chapters/ mop_2011_q3_analyses03_ragacs_tcm16-241428.pdf (accessed January 30, 2013).

Rauch, James E., 1999, "Networks Versus Markets in International Trade", Journal of International Economics, 48(1), pp. 7-35. http://dx.doi.org/10.1016/ s0022-1996(98)00009-9

Thanagopal, Thannaletchimy, 2014, "Re-estimating International Elasticities of Substitution", International Journal of Economic Sciences, forthcoming, http:// www.iises.net/journal-of-economic-sciences.

Thanagopal, Thannaletchimy and Félix Housset, 2014, "A Restricted Source Differentiated Almost Ideal Demand System, Augmented with Quality in the study of French imports", Working paper, No. 698, San Rafael, CA: Forum for Research and International Trade, http://www.freit.org/WorkingPapers/Papers/ TradePolicyGeneral/FREIT698.pdf (accessed January 20, 2013).

Trésor-Economics, 2009, "French and German Export Specialization: Similarity or Divergence", No. 68, Paris: Ministère de l'Économie de l'Industrie et de l'Emploi, https://www.tresor.economie.gouv.fr/file/327027 (accessed January 20, 2013). 